\title{
NanoZnO-modified titanium implants for enhanced anti-bacterial activity, osteogenesis and corrosion resistance
}

Zheng Wang ${ }^{1,2}$, Xiaojing Wang ${ }^{2,3}$, Yingruo Wang ${ }^{4}$, Yanli Zhu ${ }^{2}$, Xinqiang Liu ${ }^{1,2^{*}}$ and Qihui Zhou ${ }^{1,2^{*}(\mathbb{C})}$

\begin{abstract}
Titanium (Ti) implants are widely used in dentistry and orthopedics owing to their excellent corrosion resistance, biocompatibility, and mechanical properties, which have gained increasing attention from the viewpoints of fundamental research and practical applications. Also, numerous studies have been carried out to fine-tune the micro/ nanostructures of Ti and/or incorporate chemical elements to improve overall implant performance. Zinc oxide nanoparticles (nano-ZnO) are well-known for their good antibacterial properties and low cytotoxicity along with their ability to synergize with a variety of substances, which have received increasingly widespread attention as biomodification materials for implants. In this review, we summarize recent research progress on nano-ZnO modified Ti-implants. Their preparation methods of nano-ZnO modified Ti-implants are introduced, followed by a further presentation of the antibacterial, osteogenic, and anti-corrosion properties of these implants. Finally, challenges and future opportunities for nano-ZnO modified Ti-implants are proposed.
\end{abstract}

Keywords: Titanium implants, Nano-ZnO, Anti-bacteria, Osteogenesis, Anti-corrosion

*Correspondence: dentistlxq@163.com; qihuizhou@qdu.edu.cn

${ }^{2}$ School of Stomatology, Qingdao University, Qingdao 266003, China

Full list of author information is available at the end of the article

(c) The Author(s) 2021. Open Access This article is licensed under a Creative Commons Attribution 4.0 International License, which permits use, sharing, adaptation, distribution and reproduction in any medium or format, as long as you give appropriate credit to the original author(s) and the source, provide a link to the Creative Commons licence, and indicate if changes were made. The images or other third party material in this article are included in the article's Creative Commons licence, unless indicated otherwise in a credit line to the material. If material is not included in the article's Creative Commons licence and your intended use is not permitted by statutory regulation or exceeds the permitted use, you will need to obtain permission directly from the copyright holder. To view a copy of this licence, visit http://creativecommons.org/licenses/by/4.0/. The Creative Commons Public Domain Dedication waiver (http://creativeco mmons.org/publicdomain/zero/1.0/) applies to the data made available in this article, unless otherwise stated in a credit line to the data. 


\section{Graphical Abstract}

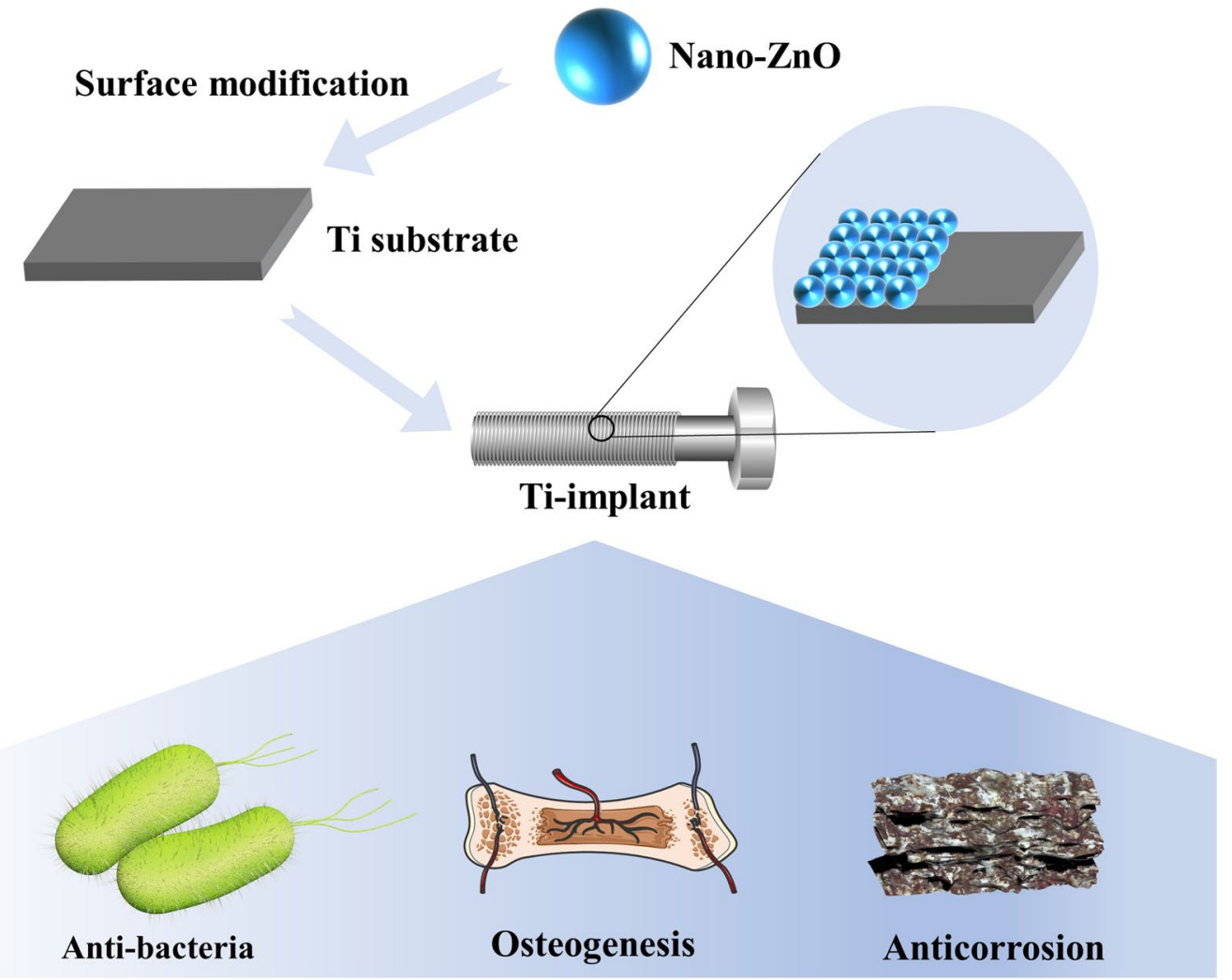

\section{Introduction}

The development of implants with both high strength and biosafety has long been a hotspot in the field of biomedical engineering [1-3]. Due to their excellent corrosion resistance, superior mechanical properties and biocompatibility, titanium (Ti) implants have been widely used in orthopedic surgery, oral implantation, and other medical devices [4-6]. However, two major issues have arisen in their clinical application: implant-related infection and poor osteogenesis [7-10].

The microbial attachment associated with Ti-implants is the major cause of postoperative implant infection. To date, microbial infection remains one of the most common and serious clinical complications after traumatic implantation [11]. Microbial infection is commonly caused by bacterial adhesion and biofilm formation on the implant surface [12]. In the clinic, implant-associated bacterial infection can lead to implant loosening in situ and soft tissue damage. Such tissue damage often leads to chronic and/or recurrent diseases if not treated timely and properly $[13,14]$. Besides, bacteria bonded to the surface of the implant to form a biofilm that prevents cells from attaching to the implant surface, further aggravating the loosening of the implant in bone tissue [12]. In patients with poor bone quality, the repair of necrotic tissue is difficult to manage due to the poor vascularity of infected bone tissue, resulting in a particularly long treatment process with a poor prognosis $[15,16]$.

Another tough problem with Ti implants that remains to be solved is their insufficient osteogenic, osteoinductive, and osseointegration abilities $[17,18]$. Commercial Ti-implants cannot completely meet the demand of clinical applications due to their bio-inert nature, and they are easily covered by a dense oxide film, particularly under conditions of poor or insufficient bone. Besides, Tiimplants are mainly bonded in the body through physical chimerism, which leads to a lack of stability and a tendency toward loosening or shedding with long-term use [19]. Only through excellent osseointegration can an implant be guaranteed to be stable and safe in the long term. In addition, there is a difference in the coefficient of thermal expansion between Ti-implants and bone, which also contributes to the unstable bond between them. Therefore, how to effectively improve the osseointegration of implants has long been of great concern. Ideal osseointegration shown under light microscopy is 
characterized by close apposition of the implant to the adjacent bone tissue without any fibrous tissue infiltration [20-23]. Mechanical treatment of Ti implant surfaces has been demonstrated to effectively improve the mechanical clamping force between the implant and the bone tissue. However, in clinical applications, the actual bonding ability is still not sufficiently sustainable [24, $25]$. Furthermore, the implants bond slowly to bone tissue, usually over 3-6 months, and the prolonged recovery time resulting from this slow bonding also limits the application of $\mathrm{Ti}$ implants. Indeed, improving the osseointegration of $\mathrm{Ti}$ implants requires a better understanding of the mechanisms of induced osteogenesis. In addition, researchers have recently realized that the immune system may play a role in bone regeneration that should not be underestimated. Immune cells, such as macrophages and $\mathrm{T}$ cells, actively balance osteoclastogenesis and osteogenesis by secreting molecules such as RANKL protein, interferon-gamma, and inflammatory cytokines in communication with various bone cells $[26,27]$. Although biomaterials for bone regeneration have been studied progressively over the years, the role played by immune cells in this process has not been fully demonstrated [28]. Therefore, a deeper knowledge of the role of immune cells in the integration of biomaterials for bone regeneration may help overcome the current dilemma of inefficient osseointegration of implants.

It is also worth noting that during the post-implantation period, Ti implants are exposed to the electrolyte environment of human body fluids, which undergo biochemical reactions at the interface between the $\mathrm{Ti}$ implant and bone tissue [29]. These adverse reactions in the physiological environment could lead to electrochemical corrosion of the implant surface, thereby reducing the longevity of the Ti implant. To this end, surface treatment of $\mathrm{Ti}$ implants is an effective way to prevent postoperative implant infection, improve the ability of osseointegration, and enhance corrosion resistance. Therefore, it is generally considered that surface modification is a direct and effective approach to endow new interfacial properties to Ti implants while retaining their original advantages [30].

In recent decades, nanomaterials have been found to possess an ultra-small size, high specific surface area, high reactivity, tunable surface modification capacity, and antimicrobial activity [12, 21, 31-35]. Meanwhile, the application of nanotechnology in biomedicine is rapidly becoming the main driving force behind the changes that are taking place in the field of antimicrobials as well as tissue repair and regeneration [36-42]. In particular, inorganic nanoparticles, such as $\mathrm{ZnO}, \mathrm{CuO}$, and $\mathrm{Ag}$ nanoparticles, have shown effective antimicrobial activity against pathogenic microorganisms and have been widely used on implants $[43,44]$. However, large amounts of heavy metals in implants (e.g., $\mathrm{Ag}$ and $\mathrm{Cu}$ ) accumulate in human bones and other tissues over time, with serious chronic toxicity effects [45].

Notably, as an amphoteric metal oxide, $\mathrm{ZnO}$ has attracted wide attention for its strong and broad-spectrum antimicrobial, antitumor, low toxicity, and various other properties [46-48]. In particular, nanoscale $\mathrm{ZnO}$ particles (nano- $\mathrm{ZnO}$ ), which have been approved for human use by the U.S. Food and Drug Administration (USFDA), exhibit attractive antibacterial properties because $\mathrm{Zn}^{2+}$ and reactive oxygen species (ROS) are released by nano- $\mathrm{ZnO}[49,50]$. Also, zinc is an essential trace element in cell development, DNA synthesis, enzyme activity, and biomineralization [51]. A proper amount of zinc on the surface of biomaterials has been confirmed to stimulate bone cells and induce a range of in vivo behaviors, e.g., adhesion, spreading, proliferation, osteogenic differentiation, osteogenesis, and mineralization $[48,52,53]$.

In this review, current strategies in the use of nano$\mathrm{ZnO}$ material modified onto the surface of Ti implants were summarized (Fig. 1) and the relevant literatures involved were also categorized (Table 1). Next, we highlighted the enhancement properties of nano- $\mathrm{ZnO}$ coatings on Ti implants in terms of antimicrobial, osteogenesis, and anti-corrosion abilities. Finally, future challenges and opportunities in the clinical use of nano- $\mathrm{ZnO}$ coatings on Ti implants were discussed.

\section{Fabrication of nano-ZnO modified Ti materials and their biosafe properties Methods for preparing nano-ZnO modified Ti implants Electrodeposition}

Electrochemical deposition is a technique in which an electric current is passed through an electrolyte solution under the action of an external electric field and a redox reaction occurs at the electrode to form a coating. As an in situ formation technique, electrochemical deposition can form well-adhered, uniformly distributed, and high purity nano- $\mathrm{ZnO}$ at various Ti-substrate interfaces, which is particularly suitable for surface modification of biomedical implants. Studies have found that both the zinc content and the fine-tuning of the hierarchical topography can be controlled by adjusting the timing of the electrochemical deposition of $\mathrm{ZnO}$ nanorods. $\mathrm{ZnO}$ nanorods were electrodeposited on the walls of pores prepared by micro-arc oxidation (MAO) to produce a micro/nano hierarchical structure suitable for biomedical applications [54]. It was found that the density of $\mathrm{ZnO}$ nanorods on the surface of the Ti-substrate changed with the duration of deposition, and the longer the deposition time was, the higher the density [55]. When the 


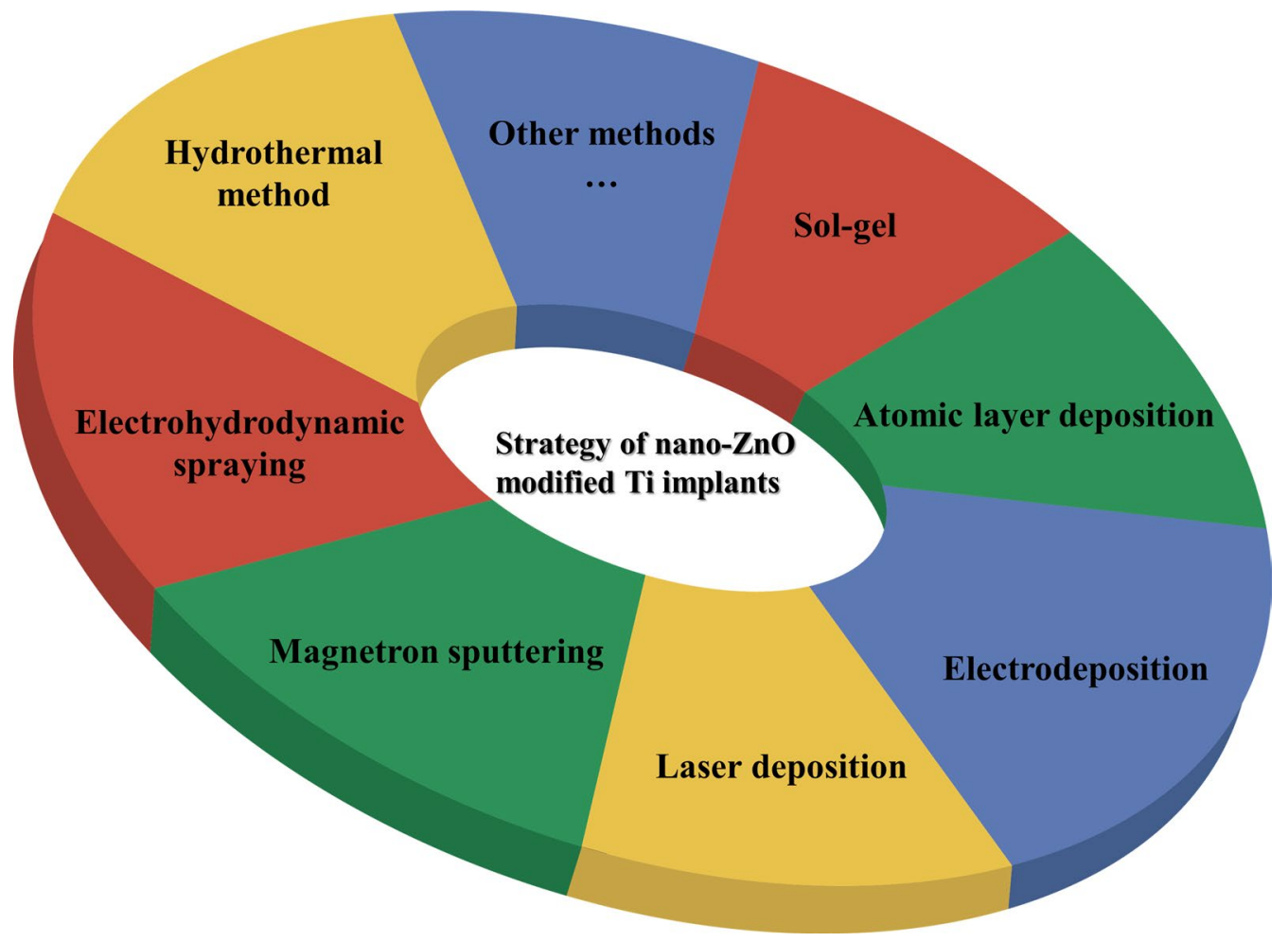

Fig. 1 Main strategies of nano-ZnO modified Ti implants

concentration of $\mathrm{Zn}^{2+}$ ions in the electrolyte was $2.5 \mathrm{mM}$, the diameter of the $\mathrm{ZnO}$ nanorods was approximately $200 \mathrm{~nm}$, and the length was approximately $2 \mu \mathrm{m}$. However, when the $\mathrm{Zn}^{2+}$ ion concentration was increased to $5 \mathrm{mM}$, a larger $\mathrm{ZnO}$ nanorod diameter was observed, reaching $300 \mathrm{~nm}$ with a similar length of approximately $2 \mu \mathrm{m}$. The above results show that modulating the concentration of $\mathrm{Zn}^{2+}$ ions during electrodeposition has little effect on the length of $\mathrm{ZnO}$ nanorods, although it is capable of causing a drastic change in diameter [55]. Similar results were observed by Yao et al., in which irregular $\mathrm{ZnO}$ nanorods were doped into $\mathrm{TiO}_{2}$ nanotubes (TNTs) in the electrodeposition method by varying the concentration of the electrolyte bath solution and reaction time [56]. In addition, Chang et al. used an electroplating method to deposit $\mathrm{ZnO}$ coatings with different thicknesses onto Ti plates at voltages of $2.0,2.25$, and $2.5 \mathrm{~V}$. Bacterial adhesion was lowest in the $2.5 \mathrm{~V} \mathrm{ZnO}$ sample, indicating the highest antibacterial activity [57]. Moreover, a $\mathrm{ZnO}$-containing $\mathrm{TiO}_{2}$ coating can also be prepared in one step by employing the MAO technique using electrolytes containing $\mathrm{Zn}^{2+}$ ions, and this nano- $\mathrm{ZnO}$ modification strategy is more efficient $[51,58]$.

Apart from single $\mathrm{ZnO}$ coatings, composite coating fabrication is another approach to improve antibacterial properties [59]. Similarly, hybrid coatings prepared by electrodeposition of functional substances [e.g. $\mathrm{Sr}^{2+}$ ions and hydroxyapatite (HA)] doped in nano- $\mathrm{ZnO}$ electrolytes have been used to enhance the corrosion resistance and biocompatibility of Ti implants [60]. However, when direct current is applied, there is a tendency for concentration polarization and the formation of loose and poor adhesion coatings on the substrate surface. Recent studies have shown that adopting pulsed electrochemical deposition is an effective way of controlling the reaction rate and has the ability to trigger intermittent energization mechanisms during operation [61], which reduces the electrolyte concentration polarization, increases deposition efficiency and generates nano- $\mathrm{ZnO}$ crystals of uniform size on the surface of Ti substrates.

Electrophoretic deposition (EPD) is also an attractive method that uses the phenomenon of charged particles moving in an electric field to apply coatings of different thicknesses onto a $\mathrm{Ti}$ implant surface and is suitable for large and complex shapes of implants [62]. One study used different deposition voltages to electrophoretically deposit coatings onto a Ti-implant surface for the same time and then sintered them in an air/vacuum atmosphere. The results showed that the hardness values of the samples and the denseness of the coatings are related to the gas environment and the voltage intensity. [62]. Electricity plays an important role in electrodeposition 
Table.1 Overview of different fabrication strategyies, morphologies, and doping elements of nano-ZnO modified Ti and their applications

\begin{tabular}{|c|c|c|c|c|}
\hline Strategies & Morphologies & Doping elements & Applications & References \\
\hline \multirow[t]{8}{*}{ Electrodeposition } & Nanoparticles & $\mathrm{Ag}$ & Anti-bacteria & [54] \\
\hline & Nanoparticles & - & $\begin{array}{l}\text { Anti-bacteria, anti-inflammation } \\
\text { inhibition }\end{array}$ & [56] \\
\hline & Nanoparticles & - & Anti-bacteria, anti-corrosion & [58] \\
\hline & Nanoparticles & $\mathrm{HA}, \mathrm{Ag}, \mathrm{Cu}$ & Anti-bacteria, osteogenesis & {$[61,91]$} \\
\hline & Nanorods & - & Not reported & [55] \\
\hline & Nanorods & - & Anti-bacteria & [57] \\
\hline & $\begin{array}{l}\text { Nanospheres, nanoflakes, worm- } \\
\text { like and flower-like structure }\end{array}$ & - & Anti-corrosion & [92] \\
\hline & Not reported & Ag, chitosan, gelatin & Anti-bacteria & [59] \\
\hline Electrophoretic deposition & Nanoparticles & - & Anti-corrosion, anti-bacteria & [62] \\
\hline \multirow[t]{3}{*}{ Atomic layer deposition } & Nanoparticles & $\begin{array}{l}\text { Sr, octadecylphosphonic acid- } \\
\text { toluene }\end{array}$ & Anti-bacteria, osteogenesis & [64] \\
\hline & Not reported & - & Anti-bacteria, osteogenesis & [48] \\
\hline & Nanoparticles & Chitosan & Anti-bacteria, osteogenesis & [52] \\
\hline \multirow[t]{2}{*}{ Magnetron sputtering } & Nanoparticles & - & Anti-biofilm, immunoregulation & [66] \\
\hline & Not reported & $\mathrm{Ta}_{x} \mathrm{O}_{y}$ & Anti-bacteria, anti-corrosion & [67] \\
\hline \multirow[t]{2}{*}{ Laser deposition } & Not reported & $\mathrm{Ag}, \mathrm{HA}$ & Anti-bacteria, osteogenesis & [46] \\
\hline & Not reported & - & Osteogenesis & [69] \\
\hline Electrohydrodynamic spraying & Nanoparticles & $\mathrm{HA}$ & Anti-biofilm & [70] \\
\hline Sol-gel & Not reported & $\mathrm{Ag}$ & Anti-bacteria, anti-corrosion & [73] \\
\hline \multirow[t]{5}{*}{ Hydrothermal method } & Nanorods & $\mathrm{Ag}, \mathrm{PLGA}$ & Anti-bacteria, osteogenesis & [76] \\
\hline & Nanorods & $\mathrm{Ag}$ & Anti-bacteria & [77] \\
\hline & Nanoparticles & - & $\begin{array}{l}\text { Anti-bacteria, osteogenesis, } \\
\text { immunoregulation }\end{array}$ & [53] \\
\hline & Nanoparticles & - & Anti-bacteria, osteogenesis & [74] \\
\hline & Nanoparticles & $\mathrm{HA}$ & Anti-bacteria & [93] \\
\hline \multirow[t]{7}{*}{ Other methods } & Not reported & Functional molecules & Osteogenesis, anti-corrosion & {$[71,72]$} \\
\hline & Quantum dots & Antibiotic, folic acid (FA) & Anti-bacteria, seal-platform & [81] \\
\hline & Nanoparticles & Chitosan & Anti-bacteria, anti-corrosion & [80] \\
\hline & Nanoparticles & $\begin{array}{l}\text { N-halamine, polystyrene-acrylic } \\
\text { acid, } \mathrm{SiO}_{2}\end{array}$ & Anti-bacteria, osteogenesis & [78] \\
\hline & Not reported & HA & Anti-bacteria & [82] \\
\hline & $\begin{array}{l}\text { Nanorods-nanospheres hierarchi- } \\
\text { cal structure }\end{array}$ & - & Anti-bacteria & [79] \\
\hline & $\begin{array}{l}\text { Nanorods-nanoslices hierarchical } \\
\text { structure }\end{array}$ & - & Anti-bacteria & [83] \\
\hline
\end{tabular}

technology, but accurate preparation of the required morphology and quantity of nano- $\mathrm{ZnO}$ on the surface of Ti substrates remains to be solved in the future.

\section{Atomic layer deposition}

Unlike electrodeposition, atomic layer deposition (ALD) can accurately control the thickness of the deposited film at the atomic scale or monolayer level, which facilitates the preparation of homogeneous coating on the surfaces with specific conditions (e.g. complex micro/nano structures, high aspect ratios, porous surfaces) [63, 64].
The 1D nanostructure of $\mathrm{ZnO}$ on carbon nanotube/chitosan-modified Ti implants produced using atomic layer deposition was first introduced by Zhu et al. By adjusting the cycling number, the thickness of $\mathrm{ZnO}$ and the $\mathrm{Zn}$ content can be precisely controlled, which not only regulated the proliferation and osteogenic differentiation of osteoblasts but also showed good antibacterial properties [52]. In the same way, the $\mathrm{ZnO}$ seed layer was also prepared by atomic layer deposition (ALD), which has uniform and narrow particles with an average size of $20 \mathrm{~nm}$, and the thickness of this layer was approximately $40 \mathrm{~nm}$ 
[65]. However, as the cycling number gradually increases from 0 to 50 , the biocompatibility of the material shows a tendency to ramp up and down, indicating the toxicity of nano- $\mathrm{ZnO}$ sheets with excessive thickness [48]. Therefore, the control of cycle parameters in ALD technology is a decisive means to affect the biological properties of materials.

\section{Magnetron sputtering}

The magnetron sputtering method is widely used to produce nano- $\mathrm{ZnO}$ coatings, in which the apparatus mainly used a highly pure $\mathrm{ZnO}$ as the target and medical $\mathrm{Ti}$ metal plates as the substrate for depositing nano-ZnO. By precisely regulating the deposition time during the sputtering process, $\mathrm{ZnO}$ specimens ranging from discrete nanoparticles to continuous films were prepared, which led to a significant development in the surface morphologies [66]. On the surface of Ti6Al4V, Ding et al. successfully prepared a $\mathrm{ZnO}$-doped tantalum oxide multilayer composite coating $\left(\mathrm{ZnO}-\mathrm{Ta}_{\mathrm{x}} \mathrm{O}_{\mathrm{y}}\right)$ by magnetron sputtering which showed that the $\mathrm{ZnO}-\mathrm{Ta}_{\mathrm{x}} \mathrm{O}_{\mathrm{y}}$ coating has great potential in improving the corrosion resistance and antimicrobial performance of Ti6Al4V implants. However, the cytocompatibility and optimal design of $\mathrm{ZnO}-\mathrm{Ta}_{\mathrm{x}} \mathrm{O}_{\mathrm{y}}$ coatings (e.g., composition, coating thickness, preparation parameters) need to be further improved [67].

\section{Laser deposition}

As is well-known, it is difficult to simultaneously immobilize several components on the surface of metallic implants. Laser cladding has a broad application prospect in the modification of implant surfaces, which can change the specific surface area, surface roughness, and wettability of implants. Studies have reported that the composite coatings composed of Ag nanoparticles (nano$\mathrm{Ag}$ ), nano- $\mathrm{ZnO}$, and $\mathrm{HA}$ nanopowders with different ratios were prepared on the Ti6Al4V alloy by laser cladding, which provided good adhesion between the coatings and substrate because of local melting during the laser treatment [46]. Comparatively, laser ablation in a liquid environment is a potential alternative to surface modification of Ti substrates as it has excellent characteristics of eliminating sharp surface features and narrowing down the size distribution of nanoparticles [68]. Zhao et al. successfully developed $\mathrm{ZnO}$-coated microgrooves on Ti-6Al-4 V implants using a two-step nanosecond laser processing technique, which achieved a substrate surface with target morphology as well as rapid fixation of chemical composition [69]. However, this technique should be avoided in conjunction with the organic component of the biomodified Ti surface, as the high local temperature generated by the laser could be a serious cause of loss of biological activity.

\section{Electrohydrodynamic spraying (EHDA)}

In contrast to electrochemical deposition, the EHDA method deposits nanoparticles on the surface of the substrate by loading a suspension containing nanoparticles into a spray device and energizing it to deliver a fine spray. One study used a stainless steel needle with a diameter of $300 \mu \mathrm{m}$ to spray the content of a $1 \mathrm{~mL}$ syringe onto the substrates, delivering an optimized coating through a symmetrical conical jet spray to ensure coverage of the sample [70]. Electrostatic spraying is a simple and economical way to prepare nano- $\mathrm{ZnO}$ coatings. Particularly, it is advantageous for coating materials while maintaining their biochemical properties at low temperatures.

\section{Sol-gel}

Sol-gel technology, by which composite organic-inorganic materials are prepared at low temperature, involves hydrolysis of the constituent molecular precursors and subsequent polycondensation into a glass-like form. It is used for its ability to mass-produce nano- $\mathrm{ZnO}$ films at low cost and with favorable substrate adhesion. For instance, Trino et al. used a modified sol-gel Pechini method to obtain the $\mathrm{ZnO}$ resin precursor. The Ti surface was then treated with a strong oxidant, Piranha solution, to form hydroxyl groups, which are extremely hydrophilic and able to bond with $\mathrm{ZnO}$ to improve the adhesion of oxide thin film. The $\mathrm{ZnO}$ deposition $(\sim 100 \mathrm{~nm})$ was performed by three sequential spin coatings on a Ti substrate [71]. Taking advantage of the fact that $\mathrm{ZnO}$ films have hydroxyl groups at the end of the surface, these hydroxyl groups can be functionalized by 3-(4-aminophenyl) propionic acid (APPA) and 3-mercaptopropionic acid (MPA) molecules, thus enabling effective loading of DMP1 peptides, resulting in a more active and aggressive surface. [72]. For a better antibacterial property, $\mathrm{AgNO}_{3}$ was integrated into the $\mathrm{ZnO}$ sol to obtain the $\mathrm{ZnO} / \mathrm{Ag}$ sol [73]. Although the sol-gel method is simple and convenient, it is inevitable to mixed with other methods to prepare Tibased nano- $\mathrm{ZnO}$ thin films.

\section{Hydrothermal method}

The hydrothermal method has been widely used in the preparation of $\mathrm{ZnO}$ with nanorod structures. Changing the factors, such as reaction temperature, vessel pressure, and reaction time, may affect the growth of $\mathrm{ZnO}$ nanocrystals on the substrate surface $[74,75]$. Seed layers can be prepared on the surface of Ti substrates and then hydrothermally treated to aid their growth [76, 77], or nano- $\mathrm{ZnO}$ can be prepared directly on the substrate surface in a sealed pressure vessel [74]. The method of preparing nano- $\mathrm{ZnO}$ coatings by dissolving the $\mathrm{Zn}$-containing compound in a heated solvent and crystallizing 
the nanoparticles on the substrate surface has the advantages of complete grain development, high purity and uniform distribution, and the possibility of using cheaper raw materials compared to other methods. However, although the hydrothermal method has been widely used in the study of preparing $\mathrm{ZnO}$ with nanorod structures, its characteristics, such as the time-consuming preparation process and the relatively single coating composition, should not be ignored.

\section{Other methods}

Ti substrates can also be coated with hybrid nanoparticles containing-ZnO by the drop dipping method through hydrogen bonding [78-80]. Similarly, spin-coating is also another simple method for preparing thin films, which is often used in combination with other methods and has been mentioned in the previous section of this article $[71,72,81,82]$. In addition, a mix of applications is also assigned to this section [83].

\section{Biosafe properties of nano-ZnO modified Ti implants}

The biosafety of modified Ti implants has always been a concern for a wide range of research groups. To ensure reliable implantation and long-lasting use in vivo, biocompatibility is an essential characteristic that the material must possess $[4,84,85]$. The cytotoxicity of nano- $\mathrm{ZnO}$ has been discussed, despite its relatively low toxicity, its application in bone still requires attention $[86,87]$. The mechanism of toxicity of nano- $\mathrm{ZnO}$ was reported to be closely related to the excessive release of $\mathrm{Zn}^{2+}$ ions and ROS generation causing cell death [88]. Excess nano- $\mathrm{ZnO}$ could produce cytotoxicity and be detrimental to cellular growth, which has been confirmed in previous studies [52, 63]. Additionally, the bonding form of nano- $\mathrm{ZnO}$ to the Ti substrate also impacts its biocompatibility. In one study it was shown that $\mathrm{ZnO}$ nanorod-coatings fabricated by the hydrothermal method were more stable and reliable than nanospherecoatings prepared by the drop dipping method, implying that an unstable modified interfacial structure would potentially result in the generation of large amounts of free nano- $\mathrm{ZnO}$ with excessive toxic effects in the local microenvironment [79]. But, when nano- $\mathrm{ZnO}$ is bound to the substrate in the same or a similar way, the cytotoxicity also varies according to its morphology, that is, rod-shaped structure inducing lower cell viability versus spherical structure [65]. The previous study has demonstrated this result and interpreted it as the lack of initial spreading on $\mathrm{ZnO}$ nanorods, which is not conducive to cell adhesion and leads to cell death [89]. Besides, modulating the releasing behavior of nanoparticles is also a key point to the biocompatibility of nano- $\mathrm{ZnO}$ modified Ti materials. The utilization of functional coatings [e.g., polydopamine (PDA), chitosan, and poly(lactic-co-glycolic acid) (PLGA)] enables effective regulation, which can mostly be attributed to physical blocking, ion chelation, and antioxidant effects [52, 65, 76, 90]. These results suggest that the nano- $\mathrm{ZnO}$ modification on $\mathrm{Ti}$ holds promise for clinical use, but the potential toxicity risks still remain to be minimized by innovative design.

\section{Antimicrobial activity of nano-ZnO modified Ti implants \\ Antimicrobial and antibiofilm mechanisms of nano-ZnO Generation of ROS}

The generation of ROS is the most widely studied and accepted mechanism underlying the antibacterial activity of $\mathrm{ZnO}$. ROS include highly reactive ionic species, and free radicals such as $\mathrm{O}^{-}, \mathrm{HO}_{2}, \mathrm{H}_{2} \mathrm{O}_{2}$, and $\mathrm{HO}$. They can damage DNA, cell membranes, and cellular proteins, and can further lead to bacterial cell death by inducing an oxidative stress response [94]. Disturbance of the balance between generated ROS and their reducing equivalents is termed oxidative stress [95-98]. Bagchi et al. fabricated the $\mathrm{ZnO}$-squaraine (SQ) dye nanohybrid aroused by nearinfrared light. The time-resolved fluorescence transient experiments verified the photoinduced interfacial electron transfer process from SQ excited state to $\mathrm{ZnO}$ conduction band, which led to the formation of ROS to a large extent [99]. The singlet oxygen sensor green reagent (SOSGR) assay analysis confirmed that the ROS produced by $\mathrm{ZnO}$ SQ were essentially singlet oxygen. The photodynamic antibacterial activity of the nanohybrids against $S$. aureus was confirmed by colony-forming unit (CFU) assays, which showed that the CFUs of $S$. aureus decreased by 95\% after photoactivated drug treatment [99]. However, the production of ROS seems to be contradictory because some studies have revealed this mechanism in the light; other studies have reported such activities even occurred in the dark [100, 101]. The possible mechanisms of ROS generated by nano- $\mathrm{ZnO}$ under light and dark conditions have been discussed in a recent report [12]. Besides, Jiang et al. revealed that the addition of free radical scavengers inhibited the bactericidal effect of $\mathrm{ZnO}$ film against E. coli, suggesting that the antimicrobial ability of nano$\mathrm{ZnO}$ is related to the generation of ROS [102]. The ionization of carboxyl, phosphate, and amino groups on the cell surface brought negative charges to the cell, which greatly affected the accumulation of nano- $\mathrm{ZnO}$ on the cell surface. Additionally, negatively charged anions, such as superoxides and hydroxyl groups, cannot enter the cytoplasmic membrane [103]. Therefore, these species exist on the outer surface of bacteria. In contrast, two HO. can be recombined to form one $\mathrm{H}_{2} \mathrm{O}_{2}$, which can pass through the cell wall of bacteria, subsequently disrupting the outer membrane, causing leakage of cytoplasmic contents, and 
DNA damage, eventually triggering cell death $[65,104]$. However, excessive ROS may cause cell damage and lead to disease in the body $[42,105]$, which indicates the need for controlled ROS production and release as well as rational design of $\mathrm{ZnO}$ application solutions on the surface of Ti implants.

\section{Release of $\mathrm{Zn}^{2+}$ ions}

One of the essential mechanisms of nano- $\mathrm{ZnO}$ antibacterial activity is the release of $\mathrm{Zn}^{2+}$ ions in aqueous media. The $\mathrm{Zn}^{2+}$ ions are released rapidly in the first few days and then gradually reach a steady-state in the following months $[54,65,81]$. The $\mathrm{Zn}^{2+}$ ions released from $\mathrm{ZnO}$ could potentially interact with bacterial surfaces, altering charge balance, and inducing cell deformation and bacteriolysis [106]. $\mathrm{Zn}^{2+}$ ions cause conformational changes in the enzymes, resulting in distortion of the active sites in the enzyme as well as competitive or non-competitive reversible inhibition [12]. The reaction of $\mathrm{Zn}^{2+}$ ions released by nano- $\mathrm{ZnO}$ with the plasma membrane, as well as the cell entry of $\mathrm{Zn}^{2+}$ ions, can destroy the ion balance in the cells, resulting in the death of bacteria. Besides, $\mathrm{Zn}^{2+}$ ions can be released from dead bacteria and then act on other bacteria, leading to a long-term antibacterial process [56]. It was found that Gram-positive bacteria were not sensitive to the damage caused by $\mathrm{Zn}^{2+}$ ions, because the toxicity of $\mathrm{Zn}^{2+}$ ions embedded in negatively charged peptidoglycans was less than that of thin peptidoglycan layered Gram-negative bacteria [107]. However, some researchers reported that the inhibitory effect of the coatings containing nano- $\mathrm{ZnO}$ on Grampositive bacteria was more significant than that on Gramnegative bacteria under the same conditions [108]. These contradictory results may indicate that the antibacterial activity of $\mathrm{Zn}^{2+}$ ions is limited. Therefore, although the dissolution of $\mathrm{Zn}^{2+}$ ions has been adopted and accepted as an antibacterial mechanism, it is still under discussion.

\section{Other possible mechanisms}

Nano-ZnO has a bactericidal effect, which depends on destroying and disordering the bacterial membrane, finally leading to the internalization of nano- $\mathrm{ZnO}$ into bacteria. The internalization of nano- $\mathrm{ZnO}$ is controlled by its particle size, surface chemistry, defects, and functionalization. Nanoparticle internalization further leads to inhibition of energy metabolism in bacteria [109]. It is reported that nano- $\mathrm{ZnO}$ had a positive charge in aqueous suspensions, and the Zeta potential of $\mathrm{ZnO}$ was $+24 \mathrm{mV}$ [110], while there was a negative charge on the bacterial surface at physiological $\mathrm{pH}$ values. Such a reverse charge can enhance the overall effect by generating electrostatic forces, which are a secure link between nanoparticles and the surface of bacteria [109].
Due to electrostatic forces, nano- $\mathrm{ZnO}$ is deposited on the bacterial surface, resulting in a curtailed cell growth rate [111]. The nanoparticles interact with and accumulate on the outer surface of the plasma membrane, which increases the surface tension and induces depolarization by neutralizing the surface potential. This electrostatic interaction leads to membrane permeability and leakage of cytoplasmic fluid, which in turn leads to cell death $[65,112]$. However, studies have suggested that electrostatic interactions are not the unique mechanism responsible for the antibacterial activity of nano- $\mathrm{ZnO}$. The surface defects of nano-ZnO, such as corner defects, edge defects, and chemical defects, have a significant effect on the antibacterial activity that induces cell wall mechanical damage $[113,114]$. In the same way, the morphology of nano- $\mathrm{ZnO}$ also causes physical damage to bacteria [65]. In addition, nano- $\mathrm{ZnO}$ plays an essential role in both immunomodulatory and antimicrobial applications. Through co-culture with innate immune cells and bacteria/lipopolysaccharide, Wang et al. found that a $\mathrm{ZnO}$ 'nanoreservoir' could enhance the phagocytosis of macrophages and inflammatory cytokine secretion of polymorphonuclear leukocytes, which contributes to its good antibacterial ability [66]. Hence, the exact mechanism of the antibacterial action of $\mathrm{ZnO}$ is not fully understood, and related research is required to validate the antibacterial contribution of each possible mechanism.

\section{Antimicrobial activity of nano-ZnO modified Ti implants Antimicrobial activity of a single nano- $\mathrm{ZnO}$ coating on $\mathrm{Ti}$ implants}

Antimicrobial studies using four types of Gram-negative bacteria associated with peri-implant periodontitis were conducted under anaerobic conditions, and the cells were stimulated with nano- $\mathrm{ZnO}$ at the concentrations of 2500 , $1000,500,250$, and $100 \mu \mathrm{g} / \mathrm{mL}$, respectively. The results showed that each species had a significant dose-dependent effect on each species [44] (Fig. 2).

Numerous studies have verified that antibacterial ability was enhanced with increasing $\mathrm{ZnO}$ content [51, 57, 58]. Liu et al. confirmed that the addition of an appropriate concentration of $\mathrm{ZnO}$ to $\mathrm{Ti}$ (the initial concentration of $\mathrm{Zn}\left(\mathrm{NO}_{3}\right)_{2}$ was $0.015 \mathrm{M}$ ) could provide excellent osteogenic properties and intense antibacterial activity for stem cell differentiation of osteocytes [74]. However, Roguska et al. reached different conclusions when obtaining different amounts of $\mathrm{ZnO}$ nanoparticles by changing the electrodeposition time, and they observed that $3 \mathrm{~min}$ of loaded nano- $\mathrm{ZnO}$ was most effective in S. epidermidis killing efficacy, while more loaded nano- $\mathrm{ZnO}$ resulted in decreased bactericidal activity [54]. Previous studies 


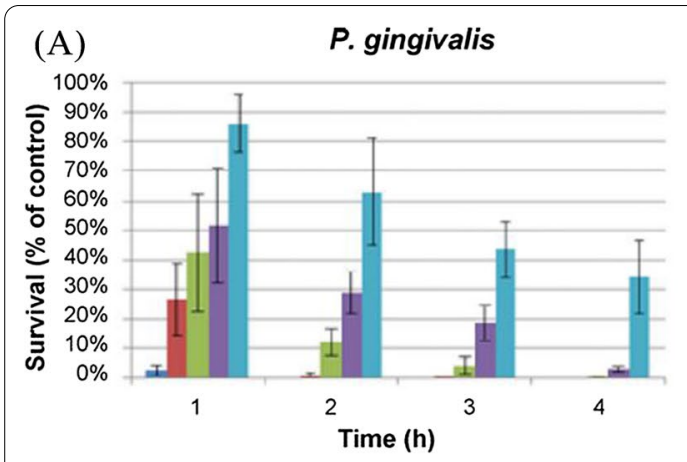

(C)

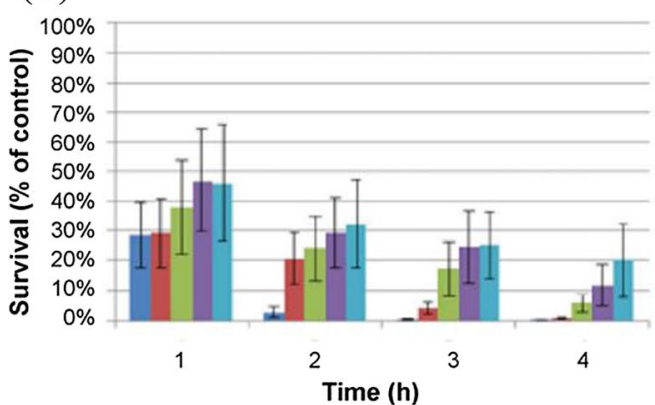

$=\mathrm{ZnO} 2500$

$=\mathrm{ZnO} 1000$

$=\mathrm{ZnO} 500$

$=\mathrm{ZnO} 250$

$=\mathrm{ZnO} 100$

$=\mathrm{ZnO} 2500$

- $\mathrm{ZnO} 1000$

$=\mathrm{ZnO} 500$

$=\mathrm{ZnO} 250$

$=\mathrm{ZnO} 100$

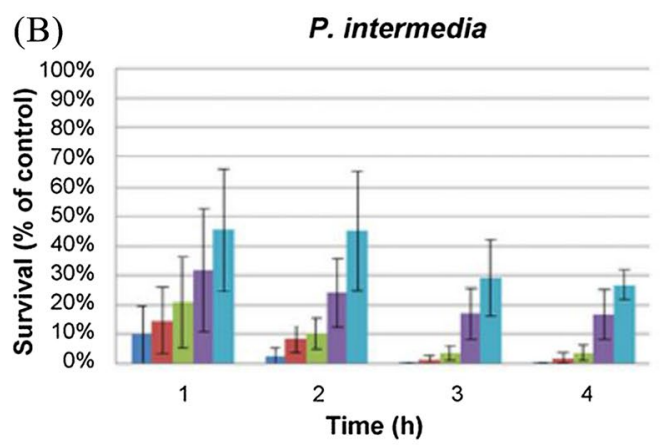

$=\mathrm{ZnO} 2500$

$=\mathrm{ZnO} 1000$

$=\mathrm{ZnO} 500$

- $\mathrm{ZnO} 250$

- ZnO 100

(D)

A. actinomycetemcomitans

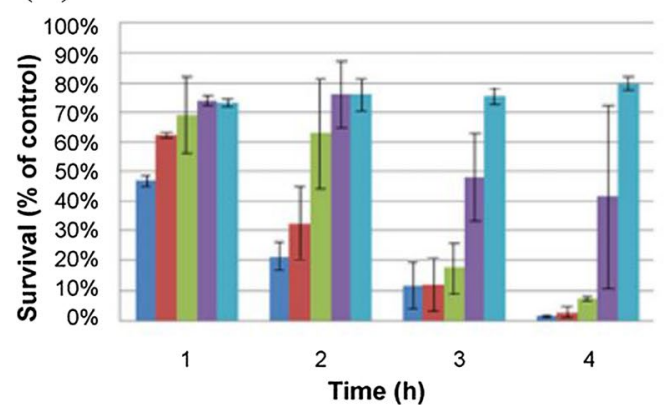

$=\mathrm{ZnO} 2500$

$=\mathrm{ZnO} 1000$

$=$ ZnO 500

$=\mathrm{ZnO} 250$

$=\mathrm{ZnO} 100$

Fig. 2 Survival rates of four anaerobic bacteria treated with five different concentrations of nano-ZnO for 1, 2, 3, and $4 \mathrm{~h}$ [44]

have attributed this to a reduction in the specific surface area of modified Ti samples as well as lower solubility of aggregated nanoparticles [115]. Therefore, the content of nano- $\mathrm{ZnO}$ on Ti substrates should be taken into consideration. If the nano- $\mathrm{ZnO}$ layer is too thick, the overdose effect will have a negative influence on the antibacterial activity of nano- $\mathrm{ZnO}$.

Nair et al. used $\mathrm{ZnO}$ particles with sizes from $1.2 \mu \mathrm{m}$ to $40 \mathrm{~nm}$, and the antibacterial activity of $\mathrm{ZnO}$ gradually increased accordingly [116]. The surface of the nanophase had a higher roughness than that of micro-phase $\mathrm{ZnO}$. The specific surface area of the nanophase was $25 \%$ higher than that of micro-phase $\mathrm{ZnO}$. Studies have shown that nano-coating may reduce the adhesion of $S$. epidermidis, thus improving the efficacy of orthopedic implants [117]. In addition, the relationship between $\mathrm{ZnO}$ particle size and antibacterial properties was also verified by Pang et al. [108].

Many studies have previously shown that the intensity of the antimicrobial ability of biomaterials was significantly influenced by their surface morphology, and researchers have compared the antibacterial effects of nano-ZnO with different morphologies [89, 118]. In contrast to irregular $\mathrm{ZnO}$ nanoparticles, $\mathrm{ZnO}$ nanorods on the TNTs surface can penetrate the bacterial membrane more efficiently and improve the antibacterial performance [56]. Similarly, Li et al. compared $\mathrm{ZnO}$ nanorod samples with $\mathrm{ZnO}$ seed layer samples ( $\mathrm{ZnO}$ particles with an average size of $20 \mathrm{~nm}$ ), and found that the tendency of $\mathrm{Zn}^{2+}$ ion release and the amount of ROS production was similar in both groups. Transmission electron microscope (TEM) images showed the membranes of bacteria cultured on $\mathrm{ZnO}$ nanorods were severely damaged, but the membranes of bacteria in another group were normal in structures and regular in shapes [65] (Fig. 3). These results revealed that the $\mathrm{ZnO}$ nanorod structure possessed essential contact-killing antibacterial activity.

Even though the implant is more susceptible to bacterial contamination during the operation [30], the durability and stability of the antimicrobial function of the implant should not be overlooked, as it is related to the resistance to bacterial infection and the long-term success of the implant. As reported, the change of $\mathrm{Zn}^{2+}$ ions release concentration in modified $\mathrm{Ti}$ by hydrothermal growth method slowed down significantly at 12 days [65], while similar results were achieved in 4 days using laser cladding technology [46]. This phenomenon indicated that different surface modification techniques resulted in variable stability of nano- $\mathrm{ZnO}$ modified Ti. Further studies demonstrated that PLGA coatings introduced to the surface of $\mathrm{ZnO}$ nanorods fabricated by hydrothermal growth technique continue to prolong the release of $\mathrm{Zn}^{2+}$ ions [76]. It implied that the long-lasting antimicrobial effect could be controlled by the modification technique 
(A)

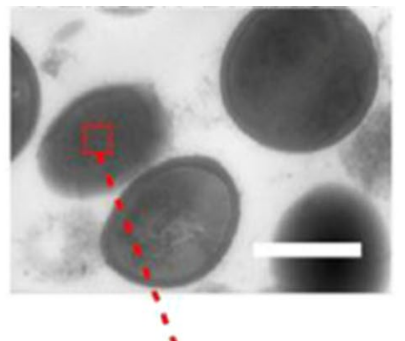

C $88.50 \%$

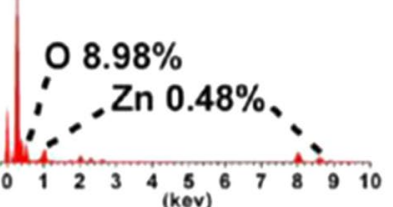

(C)
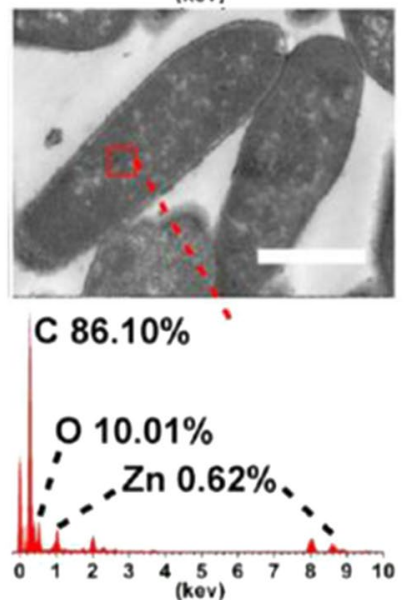

(B)
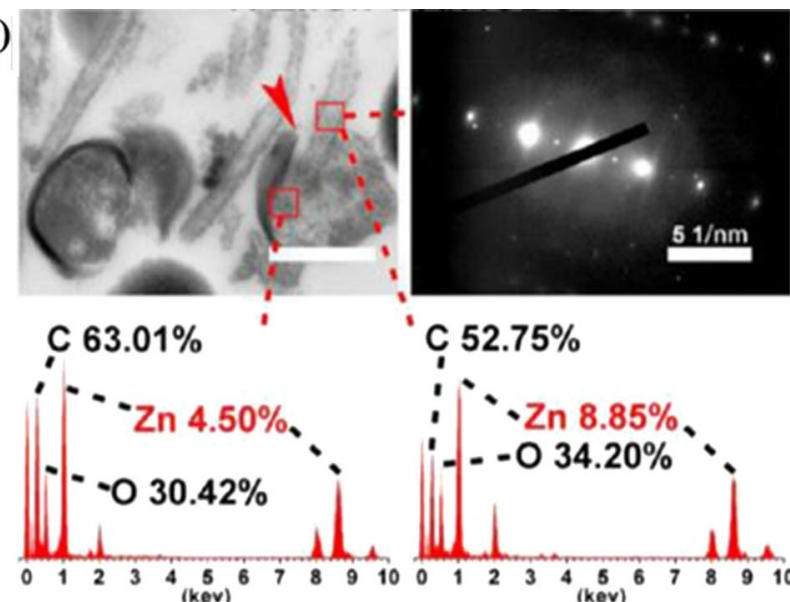

(D)
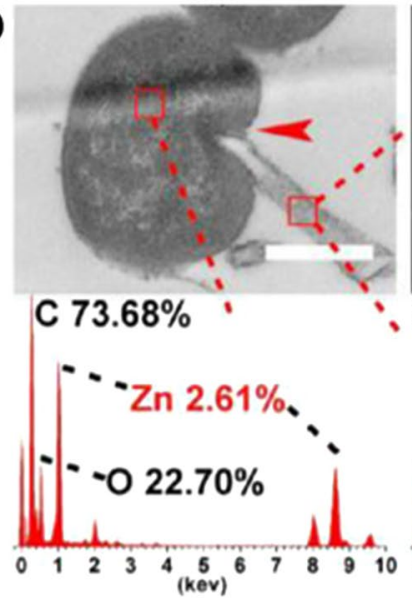
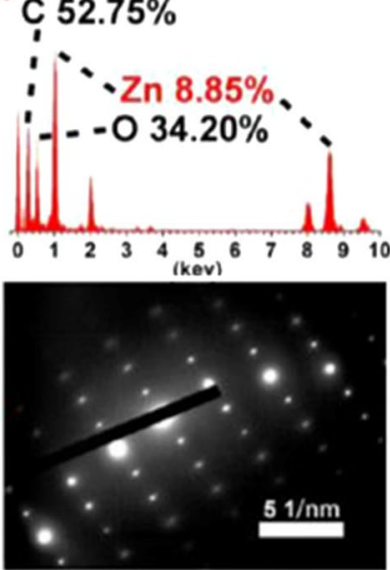

C $26.36 \%$

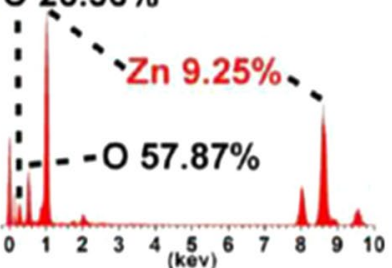

Fig. 3 TEM images of sections and the related EDS results: A S. aureus treated with ZnO seeds, B S. aureus treated with ZnO nanorods, C E. coli treated with $\mathrm{ZnO}$ seeds, and $\mathbf{D}$ E. coli treated with $\mathrm{ZnO}$ nanorods (scale bars $=500 \mathrm{~nm}$ ) [65]

approach and the introduction of polymer coatings, but the explanation for the variations of the different modification methods has not so far been reported and subsequent studies could be discussed in terms of the bond strength of nano- $\mathrm{ZnO}$ to the substrate and potential variance of surface morphology in dissolution rates. The single morphological structure of $\mathrm{ZnO}$ nanoarrays was insufficient to provide the phasic function in bacterial inhibition. Inspired by fallen leaves, Liao et al. constructed a hierarchical structure in $\mathrm{ZnO}$ nanorodsnanoslices (NHS) to modify the implant surface, which achieved the rapid release of $\mathrm{Zn}^{2+}$ ions in the early stage (within $48 \mathrm{~h}$ ) and immediately killed the bacteria around the implant. In the second stage (more than 2 weeks), the NHS showed slow release to achieve long-term inhibition. The good antibacterial activity of $\mathrm{ZnO}-\mathrm{NHS}$ was confirmed in animal experiments in vivo [83] (Fig. 4). Subsequently, a bilayer biomimetic nano-ZnO for dental implants constituting nanorods and nanospheres was found to have similar antibacterial effects, which was confirmed by exposure to the same $S$. aureus and E. coli strains [79]. Until now, almost all of the present studies have shown antibacterial effects against aerobic bacteria, but few studies have examined anaerobic bacteria.

As well, more attention should be given to the method of nano- $\mathrm{ZnO}$ use, ensuring its interaction with bones or tissue cells and that the implant shows no deleterious effects. Nano- $\mathrm{ZnO}$ coatings tend to increase the cytotoxicity of implants while improving their antibacterial capacity. Therefore, it is important to strike a balance between antibacterial capability and biocompatibility $[119,120]$. For example, Zhang et al. used the hydrothermal treatment to incorporate $\mathrm{ZnO}$ into $\mathrm{MAO}-\mathrm{TiO}_{2}$ coatings to generate a hierarchical micro/nanostructure, which has vigorous antibacterial activity but has certain toxicity toward osteoblast-like cells. However, the simple heating treatment improved cytocompatibility by increasing the crystallinity of the coating, resulting in a slow and stable release of $\mathrm{Zn}^{2+}$ ions [47]. $\mathrm{Li}$ et al. designed hybrid $\mathrm{ZnO} / \mathrm{PDA} /$ arginine-glycine-aspartic 

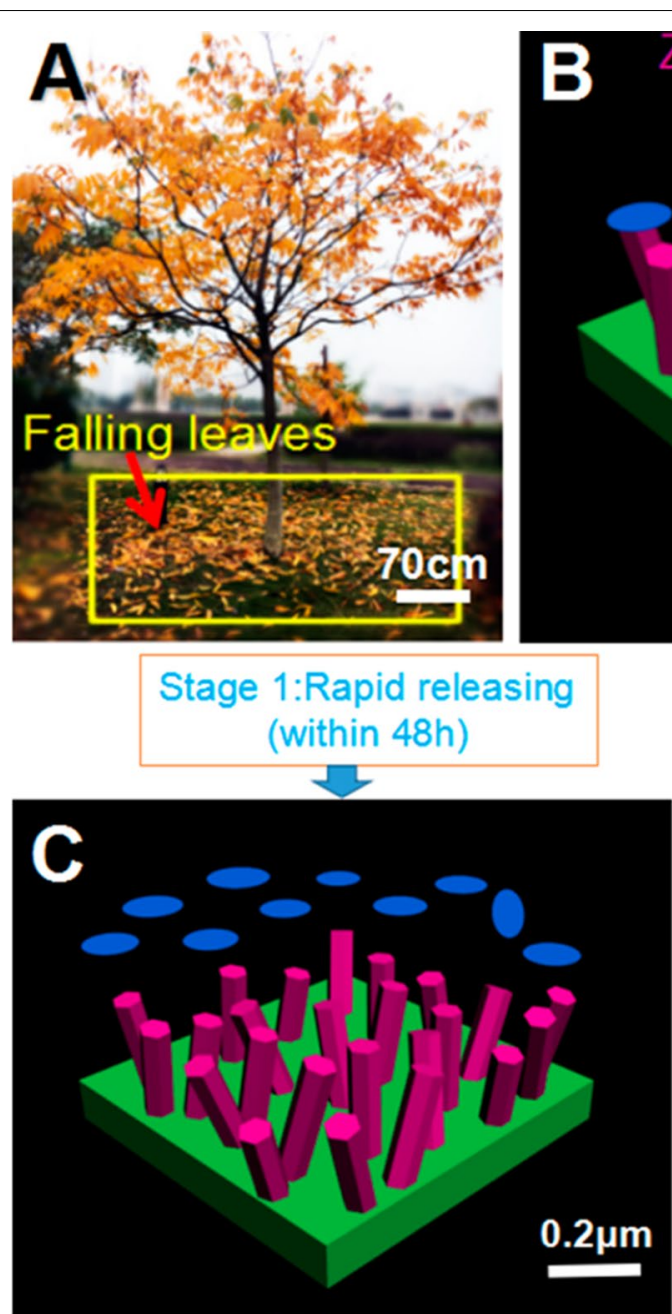

Fig. 4 Three-dimensional schematic diagram of the bilayer ZnO-NHS: A conception from the trunk-leaf model B layered structure of trunk-like ZnO nanorods and deciduous ZnO nanoslices on the substrate surface; The two-stage release: $\mathbf{C}$ fast-release phase and $\mathbf{D}$ slow-release phase [83] acid-cysteine (RGDC) nanorod arrays on Ti implants. It was also shown that the coverage of PDA and RGDC could simultaneously inhibit ROS accumulation and increase $\mathrm{Zn}^{2+}$ ion concentrations, thereby improving cell compatibility [65].

HA has almost the same chemical composition as natural bone and teeth, and the size and rigidity of nano-sized HA (nHA) are highly similar to those of HA crystals in natural bone; thus HA has good biocompatibility and osteoinductive activity, and is often used as a coating material $[121,122]$. Therefore, some scholars obtained better biocompatibility and osteoinductivity while achieving a good antibacterial effect when nano$\mathrm{ZnO}$ was doped with nHA [70, 75]. In the latest research, polypyrrole (PPy) was used as a dual regulator of nHA and nano- $\mathrm{ZnO}$ through coordinating and doping of ions, which reduced the release rate of $\mathrm{Ca}^{2+}$ and $\mathrm{Zn}^{2+}$, not only ensuring a good antibacterial effect but also improving

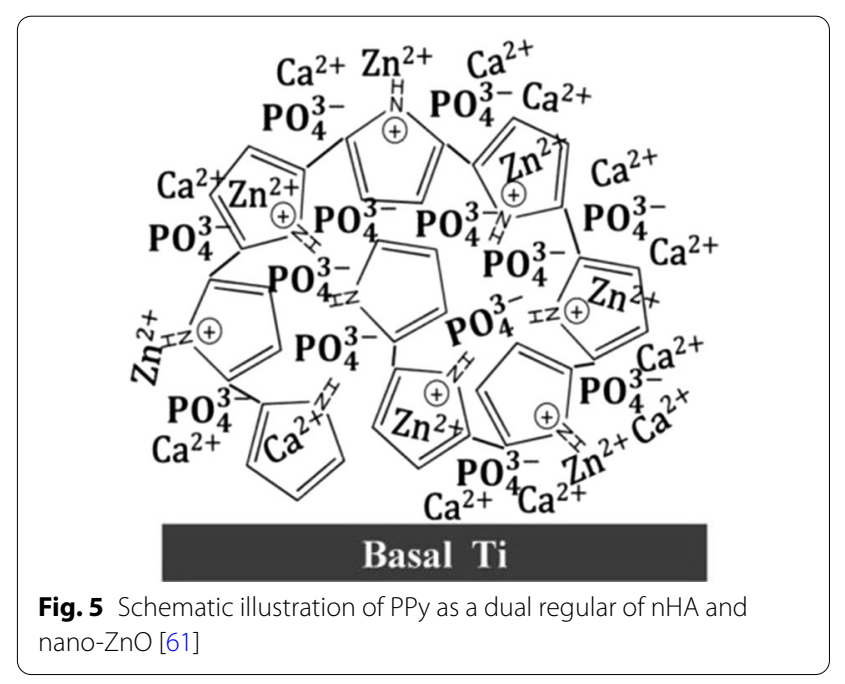


the physiological stability of the composite coating [61] (Fig. 5).

In vivo implant infections involve interactions among the implant, the bacteria, and the local host immune response [123]. Mononuclear macrophages and polymorphonuclear leukocytes (PMNs) are two essential cells in the natural immune response and serve a pivotal function in the innate defense of the host against bacterial infection [124]. To investigate the potential effect of nano- $\mathrm{ZnO}$ films on $\mathrm{Ti}$ surfaces in natural immunity against bacterial infection, Wang et al. co-cultured murine RAW 264.7 macrophages and PMNs with bacteria and found that bacterial phagocytosis was greater in all the nano- $\mathrm{ZnO}$ groups than in the Ti group [66]. To further understand the reason for this, $\mathrm{ZnO}$ films were co-incubated with macrophages exposed to bacterial irritation, and the results showed that the release of pro-inflammatory cytokines, i.e. TNF- $\alpha$, IL- 6 , monocyte chemoattractant protein-1 (MCP-1), was increased in the nano- $\mathrm{ZnO}$ group, and thus the overall effect of nano$\mathrm{ZnO}$ films promoted the local inflammatory response, resulting in the recruitment of more immune cells to fight bacterial infections. Interestingly, the secretion of anti-inflammatory cytokines (IL-10), which are antagonists of pro-inflammatory cytokines and prevent uncontrolled inflammatory responses [125], was also increased. However, in another report [56], nano- $\mathrm{ZnO}$ was used to enhance the biological properties of Ti-based implants by inhibiting macrophage activity and weakening the inflammatory response while exerting its antimicrobial efficacy. Although the current research remains controversial, it is obvious that nano- $\mathrm{ZnO}$ could modulate the immune response to assist in the elimination of bacterial infections, and future works should focus on the mechanism of action of nano- $\mathrm{ZnO}$ on inflammatory factors to control the inflammatory response.

\section{Antibacterial activity of nano-ZnO and other materials on $\mathrm{Ti}$ implants}

Using different composites can reduce the cost of potential applications and the possibility of bacterial drug resistance by optimizing the concentration of individual nanoparticles [44]. To further improve the bactericidal characteristics, the combination of nano- $\mathrm{ZnO}$ and other antimicrobial agents has been extensively studied. Recently, surface functionalization with organic antimicrobial agents has also been considered to obtain antibacterial properties on Ti surfaces [126, 127]. Antibacterial $\mathrm{N}$-halamine polymers and related coatings have been widely studied in the past decade because of their strong broad-spectrum antibacterial activity against microorganisms, long-term chemical stability, renewability, biosafety, environmental friendliness and low cost [78]. Li et al. built hybrid nanoparticles that were immobilized on a Ti surface via hydrogen bonding, endowing Ti implant material with potent antibacterial ability. And the hybrid nanoparticles were composed of N-halamine and nano$\mathrm{ZnO}$ on the surface of colloidal templates [monodispersed polystyrene-acrylic acid (PSA)]. To investigate the antibacterial activity of the nanoparticles, the samples were incubated with $P$. aeruginosa, E. coli and $S$. aureus. The results showed that $\mathrm{ZnO}$ or $\mathrm{DMH}-\mathrm{Cl}(\mathrm{DMH}$, the precursor of $\mathrm{N}$-halamine) has an obvious antibacterial effect, and the combination of $\mathrm{ZnO}$ and $\mathrm{DMH}-\mathrm{Cl}$ could enhance antibacterial efficiency [78] (Fig. 6).

In clinical practice, antibiotics are usually prescribed to prevent infection-related complications [7]. However, there are still many doubts and conflicting opinions on several aspects of using antibiotic implants after years of scientific debate, because of mutant resistance produced by long-term exposure to antibiotics below the inhibitory concentration, serious side effects, and other factors [128]. Ti implants topically loaded with antibiotics can provide sustained drug release, but non-specific release and local overdose issues make them detrimental to longterm antimicrobial action [129]. Designs with conditionresponse mechanisms are likely to be considered as a more refined solvent $[130,131]$. Xiang et al. fabricated a pH-sensitive ZnO-FA-blocked TNT drug delivery system [81]. Using TNTs modified with the antimicrobial drug vancomycin (VAN) as a drug delivery platform, folate (FA) was coupled on the surface of $\mathrm{ZnO}$ quantum dots (QDs) $-\mathrm{NH}_{2}$ by an amidation reaction to construct the blocking layer. Because of the protective effect of $\mathrm{ZnO}$-FA on the surface of TNTs, the system was stable under physiological $\mathrm{pH}$, while the dissolution of $\mathrm{ZnO}-\mathrm{FA}$ in an acidic environment was caused by bacterial infection, thus releasing VAN, and the antibacterial ratio in the TNTs-VAN-ZnO-FA groups increased significantly with the decrease of $\mathrm{pH}$ (from 60.8 to 98.8\%). Overall, the results showed that the drug delivery system has potential application prospects in bacteriostasis (Fig. 7).

Some scholars have found that the antibacterial efficacy of nano- $\mathrm{ZnO}$ against Gram-positive bacteria such as $S$. aureus is better than that against Gram-negative bacteria such as E. coli. Complementary to nano- $\mathrm{ZnO}$, nano-Ag shows potent antibacterial efficacy toward Gram-negative bacteria. In combination, $\mathrm{Ag} / \mathrm{ZnO}$ nanohybrid materials exhibit more obvious antibacterial efficacy [81]. Shang et al. prepared nano-Ag modified $\mathrm{ZnO}$ nanorod arrays and tested them against $P$. aeruginosa. Compared with other samples, the morphological structure of $\mathrm{ZnO}$ nanorods optimized the size and distribution of nano$\mathrm{Ag}$, endowing the nanorods with excellent synergistic antibacterial properties [77]. The synergistic effect of nano- $\mathrm{ZnO}$ and nano- Ag greatly improves antimicrobial 


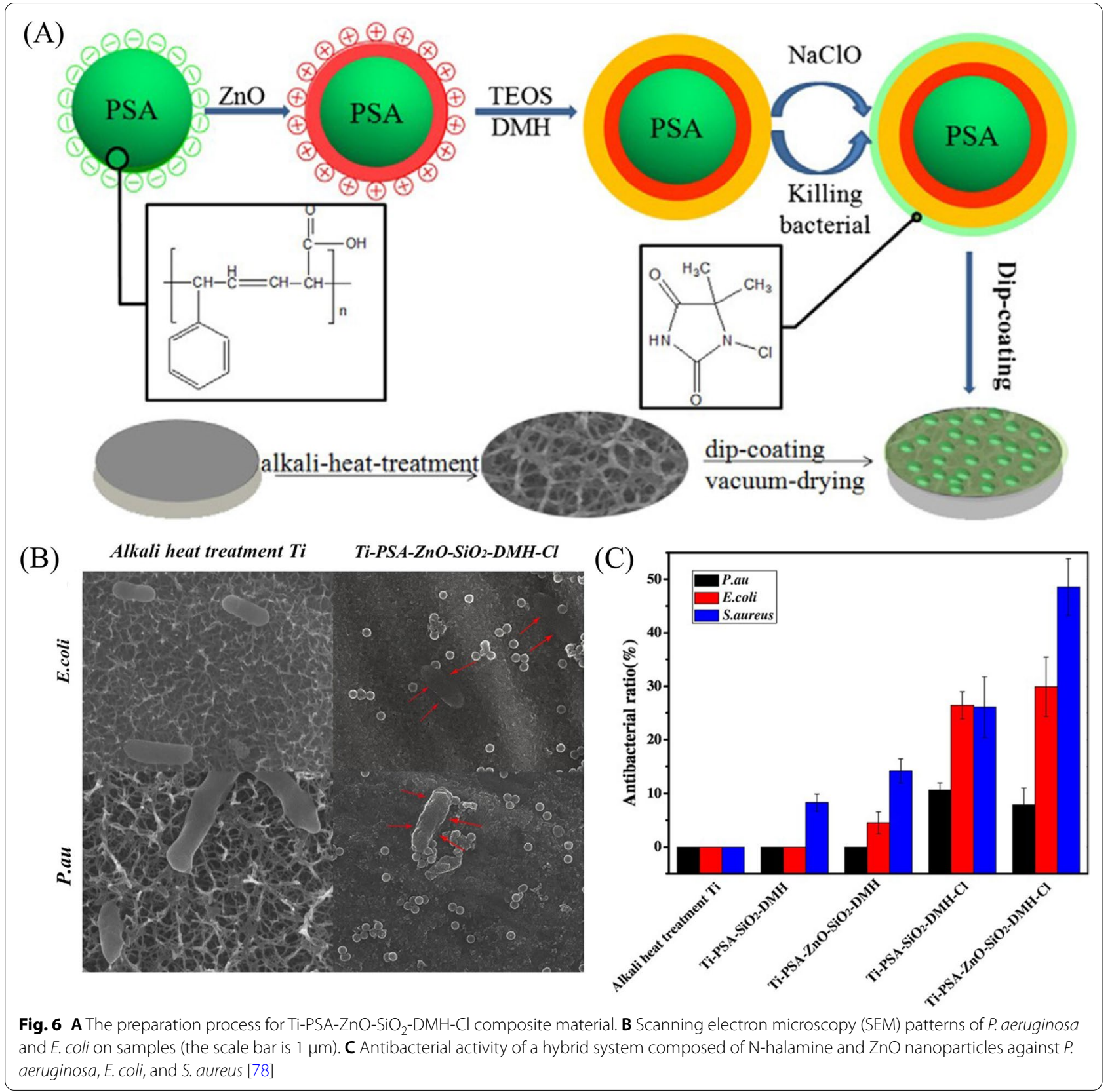

efficiency and reduces the cytotoxicity of high doses of nano-Ag and the cost of antimicrobial coatings. As mentioned above, the antibacterial function of nano- $\mathrm{ZnO}$ is highly dependent on ion-releasing behavior; excessive release of $\mathrm{Zn}^{2+}$ can produce cytotoxicity [132]. Xiang et al. solved this problem by using a sol-gel method to prepare PLGA/Ag coatings on a Ti disk with $\mathrm{ZnO}$ nanorods [76]. By using PLGA overlays to encapsulate two powerful inorganic antibacterial agents, $\mathrm{ZnO}$ and nano-Ag, the Ti implants exhibited superior antibacterial ability while avoiding potential cytotoxicity effectively
[76]. Further results showed that cellular responses varied with different initial concentrations ratios of $\mathrm{Ag} /$ $\mathrm{ZnO}$, indicating that the nano- $\mathrm{Ag} / \mathrm{ZnO}$-embedded $\mathrm{HA}$ coating $(\mathrm{Ag} / \mathrm{ZnO} / \mathrm{HA}=7: 3: 90 \mathrm{wt} \%)$ exhibited the best antibacterial effect and osteogenic ability, exemplified by the broad-spectrum antibacterial efficacy of 96.5 and $85.8 \%$ against E. coli and S. aureus, as well as by the enhanced osteoinductive ability [46]. Lately, a uniform $\mathrm{PPy}-\mathrm{HA} / \mathrm{ZnO}-\mathrm{Ag}-\mathrm{Cu}$ nanocomposite coating was constructed on Ti substrates using PPy as a regulator of HA nanoparticles and metal particles (Fig. 8). In comparison 


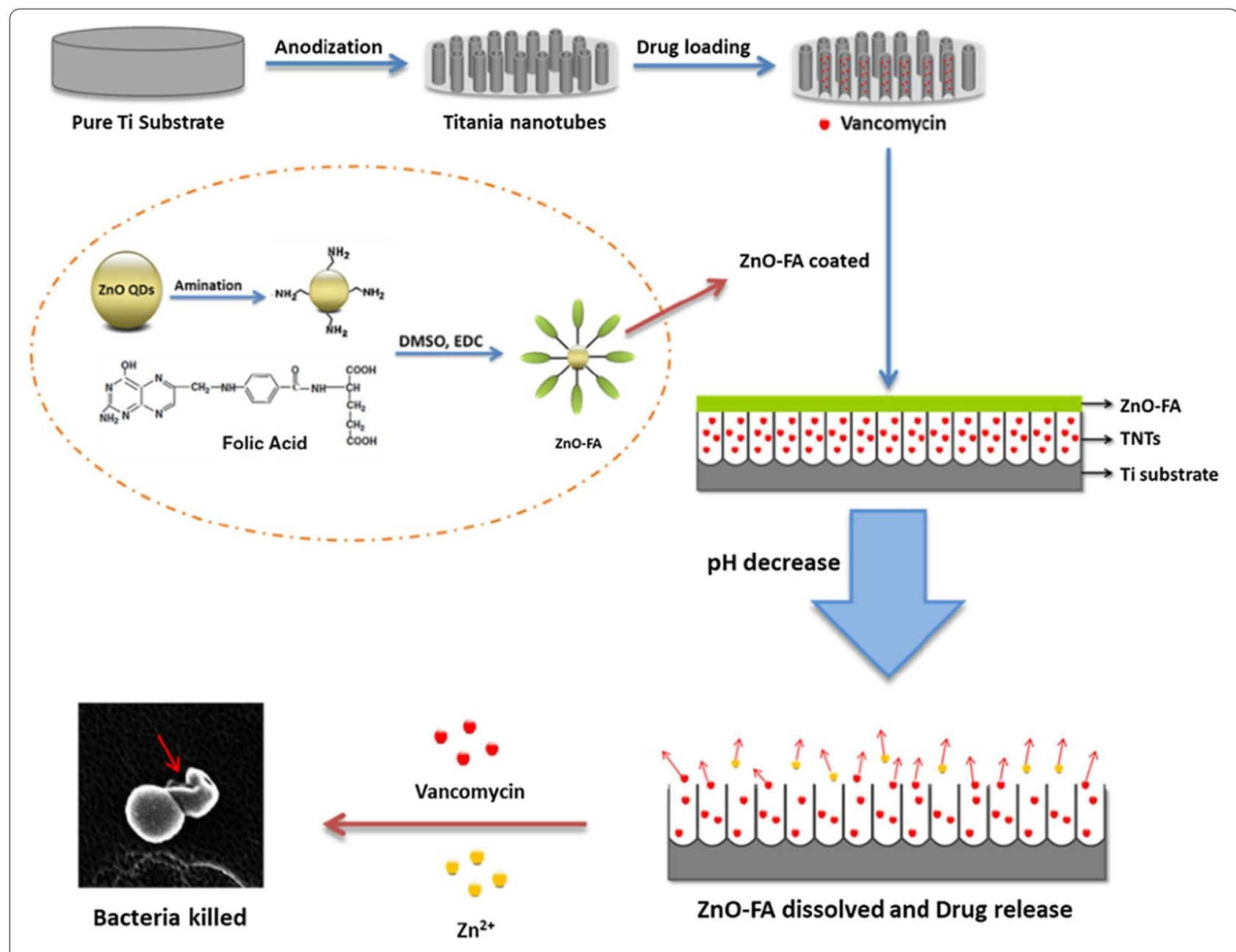

Fig. 7 Schematic diagram of preparation process of TNTs-Van@ZnO-FA system and the mechanism of pH-triggered synergistic sterilization [81]

with the pure HA coating, the multi-metal nanoparticles doped coating not only exhibited $100 \%$ inhibition of both $S$. aureus and E. coli, but also presented the required bioactivity, namely, cytocompatibility, angiogenic, and osteogenic capability as a promising candidate coating material for Ti implants [91].

Chitosan (CS) is an antimicrobial polymer with excellent biocompatibility [133]. As a notable strategy, $\mathrm{ZnO}$ containing CS-based composite coatings and their derivatives demonstrate notable potential for antibacterial applications based on antibiotic-free strategies, including cationic contact killing surface structures and the inherent antibacterial characteristics of nano- $\mathrm{ZnO}$. It was detected that the $\mathrm{CS} /$ nano- $\mathrm{ZnO}$ coating showed 1.2-fold stronger antibacterial activity against $E$. coli than the CS coating alone and actively prevented the formation of biofilm [80]. Further study was carried out by Lin et al., where a double-layer antimicrobial coating design on pure $\mathrm{Ti}$ was proposed [59]. The new double-layer included an inner layer of TNTs doped with nano-Ag (TNTs/Ag) and the outer layer of CS-gelatin (Gel) mixture containing nano-Ag and nano-ZnO (CS-Gel-Ag$\mathrm{ZnO}$ ). Further studies on the antimicrobial activities of the coating against planktonic and adherent bacteria revealed that the limited inhibitory effect of nano- $\mathrm{Ag}$ against planktonic bacteria in TNTs was compensated by the CS-Gel-Ag-ZnO layer. The antimicrobial capability of the novel composite coating of TNTs/Ag+CS-Gel$\mathrm{Ag}-\mathrm{ZnO}$ was enhanced due to the intrinsic synergistic antimicrobial activity of $\mathrm{CS}$, nano- $\mathrm{ZnO}$, and $\mathrm{Ag}$ against planktonic bacteria. The extremely high antibacterial rate of $99.2 \%$ shows a broad prospect in the field of orthopedic surgery and dental implants [59].

The hydrophilicity/hydrophobicity of a material surface is also an important factor affecting bacterial adhesion. Zhang et al. obtained a superhydrophobic Ti substrate by 


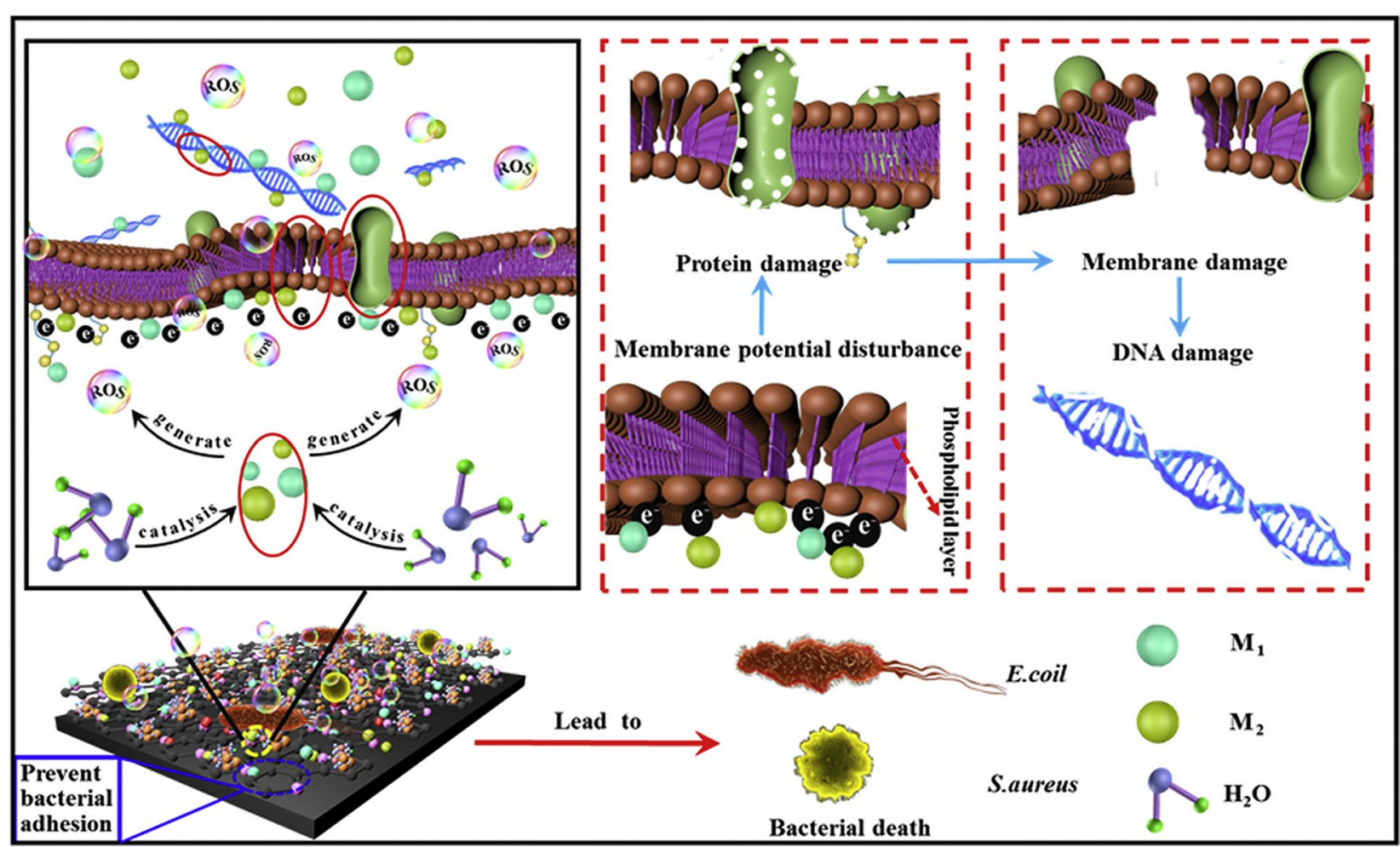

Fig. 8 Mechanism diagram of multi-metal nanoparticles composite coating against E. coli and S. aureus [91]

grafting octadecylphosphonic acid (OPDA)-toluene to resist bacterial adherence. Furthermore, OPDA modification adjusted the release rate of $\mathrm{Zn}^{2+}$ ions to achieve long-term release and consequently improve the biocompatibility of Ti-based metallic implants in regard to antibacterial effects [64].

\section{Osteogenic induction of Ti surface containing nano-ZnO}

Zinc is a trace element in the human body that is essential for the growth of the skeleton [134]. In previous studies, nano- $\mathrm{ZnO}$ was incorporated into the biomaterial surface to promote implant osseointegration and shorten the bone healing period. Here, the major form induced by osteogenesis of nanoZnO-based Ti-implants is summarized.

\section{Effect of nano-ZnO modified Ti implants on osteoblasts}

The physicochemical features at the interface of biomaterials contribute significantly to the regulation of cellular responses [41], and several studies in recent years have reported the effects produced by various nano- $\mathrm{ZnO}$ modified Ti surfaces on cells. Studies have reported that a well-defined and controlled Zn-incorporated nanotopography on the acid-etched pure Ti surface by a hydrothermal treatment was generated, and the results showed that the modification of the acid-etched $\mathrm{Ti}$ with nanostructured $\mathrm{ZnO}$ enhanced the proliferation and alkaline phosphatase (ALP) activity of osteoblast-like SaOS-2 cells in a dose-dependent manner [135]. In a subsequent study, a novel micro/nanostructured $\mathrm{TiO}_{2} / \mathrm{ZnO}$ coating (MHTZn), produced by MAO, hydrothermal treatment, and heat treatment, was designed to achieve a balance between antibacterial activity and cytocompatibility. An increased number of filopodia were observed under SEM compared to the MAO group (Fig. 9). In vitro biological experiments demonstrated that the micro/nanostructured coating with bioactive $\mathrm{Zn}^{2+}$ ions had significantly promoted cell adhesion and the expression of osteogenic activity markers, including ALP activity, collagen secretion, osteopontin (OPN), and osteocalcin (OCN) in SaOS-2 cells [136]. Similarly, in another investigation, in vitro experiments with commercially available human osteoblasts showed increased osteoblast adhesion, ALP activity, and calcium mineral deposition on nanostructured $\mathrm{ZnO}$ and $\mathrm{TiO}_{2}$ compared to microphase formulations. In addition to $\mathrm{Zn}^{2+}$ ions, the surface morphology of the coating forms local microenvironments for osteoblast growth and regulates the behavior of bone-related cells [117]. However, the excessive $\mathrm{Zn}^{2+}$ ion concentration inhibited cell growth. It has been reported that osteogenic activity is enhanced by the introduction of a 


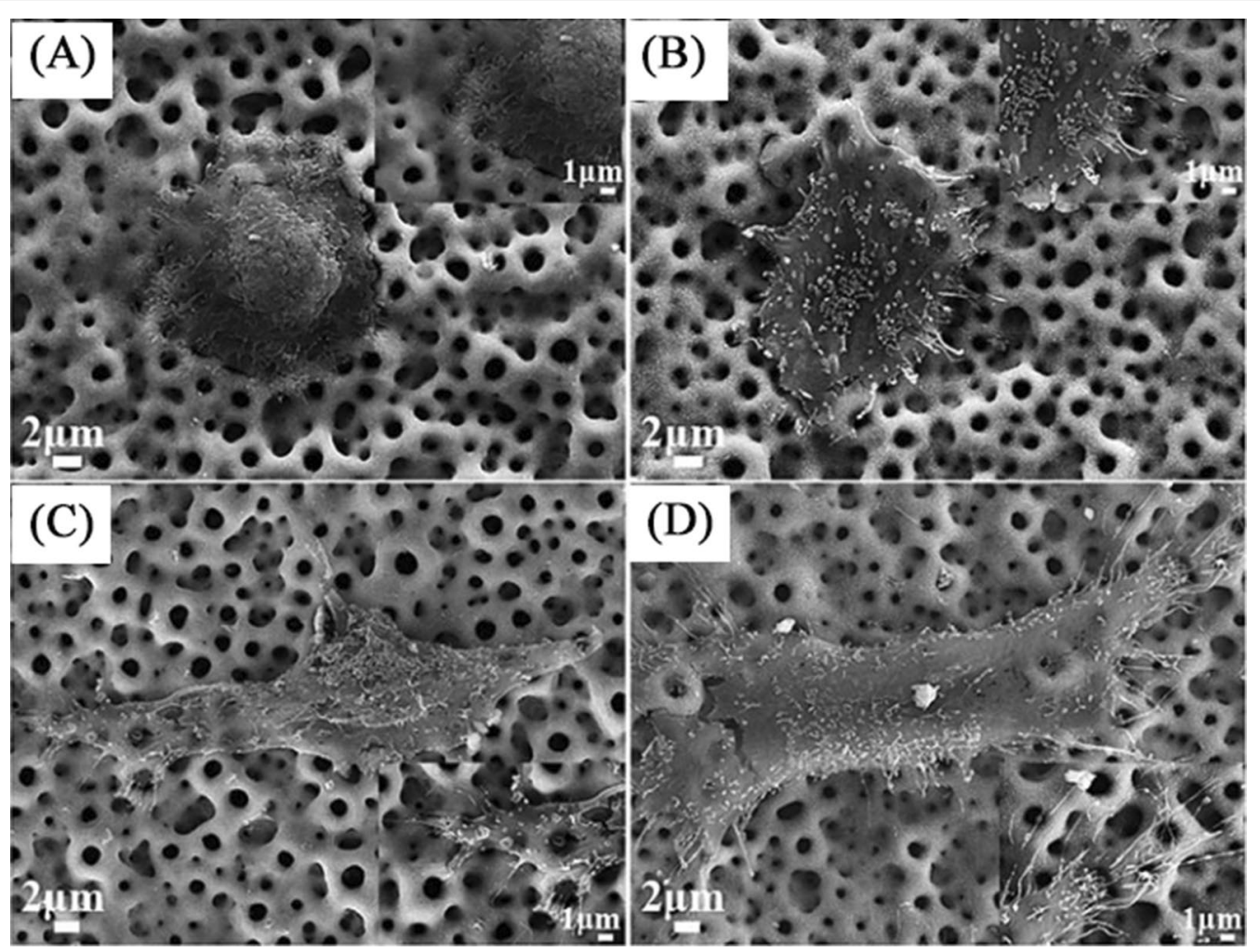

Fig. 9 SEM images of morphologies of SaOS-2 cells adhered to the MAO: A $4 \mathrm{~h}$ and C 24 h; MHTZn: B $4 \mathrm{~h}$ and $\mathbf{D} 24 \mathrm{~h}$ [136]

biodegradable PLGA coating that regulates the release of $\mathrm{Zn}^{2+}$ ions [76]. Hence, more emphasis should be given to the correlation between the physicochemical properties of $\mathrm{ZnO}$ and the osteogenic activity of osteoblasts.

\section{Effect of nano-ZnO modified Ti implants on osteoclasts}

Osteoclasts are a cell type involved in the process of osseointegration, as opposed to osteoblasts [21]. Abnormally high osteoclast activity could result in excessive bone resorption. Consequently, reducing excessive osteoclastic-induced bone resorption would facilitate implantbone integration [16]. It was reported that the binding of RANKL to RANK activates nuclear factor $\kappa B$ (NF- $\kappa B$ ), which then induces osteoclastic differentiation [137]. Zn suppressed osteoclast differentiation by antagonizing the activation of (NF-kB) and RANK expression as well as the activation of extracellular signal-regulated kinase (ERK) $[138,139]$. But, controversial results of osteoblasts being differentially subject to nano- $\mathrm{ZnO}$ were observed. In bone metabolism, tumor necrosis factor (TNF)- $\alpha$ is considered a key cytokine in inflammatory osteoclastogenesis and bone destruction. Choi et al. applied nano$\mathrm{ZnO}$ to cause bone resorption in mouse calvarial bone in vivo, and hypothesized that it possibly relates to $\mathrm{Zn}^{2+}$ ions-induced TNF- $\alpha$ release to activate osteoclasts [140].
The interaction between osteoclasts and nano- $\mathrm{ZnO}$ is quite complex, with no consistent results from current studies and few studies based on nano- $\mathrm{ZnO}$ modified $\mathrm{Ti}$ surfaces. Future implant materials should not only inhibit osteoclast-mediated bone resorption, but also modulate a dynamic balance among osteoblasts-materials-osteoclasts to achieve stable osteointegration over time.

Effect of nano-ZnO modified Ti implants on the osteogenic differentiation of mesenchymal stem cells (MSCs)

It is widely known that MSCs can be induced to differentiate into osteoblasts under specific conditions at the biomaterial interface [141]. Oh et al. found that intense stem cell elongation induced cytoskeletal stress and selective differentiation into osteoblasts to adapt to the force [142]. Subsequently, a clear research result demonstrated that the bone mesenchymal stem cells (BMSCs) on $\mathrm{Zn}$-incorporated $\mathrm{TiO}_{2}$ coatings were subjected to abnormal tension and stress. According to previous research, $\mathrm{Zn}$-incorporated $\mathrm{TiO}_{2}$ coatings had an obvious biological activity to promote the differentiation of rat BMSCs [51]. Further study suggested that the nano- $\mathrm{ZnO}$ was doped into TNTs by Liu et al., with the aim of optimizing the differentiation of MSCs and antimicrobial properties of the original $\mathrm{Ti}$ substrate. 
$\mathrm{ZnO}$ nanoparticles with tunable concentrations were incorporated into TNTs by Liu et al. using a facile hydrothermal strategy, with the aim of optimizing mesenchymal stem cell differentiation and the antibacterial properties of Ti. Through response surface mathematical model simulation and experimental verification, $\mathrm{Ti}$ incorporated with $\mathrm{ZnO}$ at appropriate concentrations (with an initial concentration of $\mathrm{Zn}^{2+}$ ions at $0.015 \mathrm{M}$ ) can provide exceptional osteogenic properties for the differentiation of MSCs among bone cells with strong antibacterial effects. Compared to the control groups, ALP activity improved to approximately $13.8 \mathrm{U} / \mathrm{g}$ protein, and the osteocalcin, collagen-I, and osterix gene expression in mesenchymal stem cells also improved [74].

\section{Effect of nano-ZnO modified Ti implants on immune cells}

Existing osteogenic mechanisms are mainly described in terms of osteoblast differentiation, largely ignoring the influence of immunomodulation on osteogenic activity. The implant is considered a foreign body during the osseointegration process [143]. The host develops immune responses after implantation, and macrophages are among the first cells to interact with implants, which occupy a vital position in the innate immune defense [144]. As the precursor of osteoclasts, macrophages can release a variety of proteins, factors, and cytokines involved in both immune regulation and bone regulation $[145,146]$. These secreted factors further affect extracellular matrix deposition and new bone formation [147].

Culturing macrophages on a nanoZnO-modified $\mathrm{Ti}$ implant (TNTs/ZnO) revealed that $\mathrm{TNTs} / \mathrm{ZnO}$ has a significant inhibitory effect on the proliferation and adhesion of macrophages and could be used to prevent chronic inflammation and control the inflammatory reaction [56, 148]. Moreover, the inflammatory responses of macrophages on the micro/nanostructured $\mathrm{TiO}_{2} / \mathrm{ZnO}$ coating were investigated by $\mathrm{Zhang}$ et al. [53], and these authors showed an increase in the expression of IL-4, IL-6, IL-10, and TNF-a in the MHTZn (the micro/nanostructured $\mathrm{TiO}_{2} / \mathrm{ZnO}$ coating) group compared to the $\mathrm{MAO}$ (macroporous $\mathrm{TiO}_{2}$ coating) group. When polarized into the M1 phenotype, macrophages mainly secrete pro-inflammatory cytokines such as TNF- $\alpha$, IL-6, and IL-12, whereas, in the M2 phenotype, the main secreted cytokines are anti-inflammatory cytokines such as IL-4, IL-10, and TGF- $\beta$ [144]. In this study, the increase in pro- or anti-inflammatory cytokines indicated that macrophages were polarized toward the M1 and M2 phenotypes, respectively. To further verify these results, they collected the medium of macrophage cell line RAW264.7 cultured on the surface of MAO and MHTZn substrates and used it as the conditioned medium to culture SaOS-2 cells. The results showed that no significant differences in proliferation were observed between the cells cultured in these two conditioned media, whereas SaOS-2 cells cultured in MHTZn conditioned medium showed an upregulation of ALP activity and increased mineralization. These findings not only confirm that MTHZn promotes the polarization of macrophages, but also simultaneously indicate that nano- $\mathrm{ZnO}$ modified Ti surfaces can enhance osteogenic properties by affecting immune cells [53]. Although the influence of macrophage cells on nano$\mathrm{ZnO}$ has been confirmed, other immune cells, such as $\mathrm{B}$ cells and $\mathrm{T}$ cells, remain to be explored.

\section{Effect of the piezoelectricity of nano-ZnO modified $\mathrm{Ti}$ implants on bone formation}

It is well known that electrical stimulation affects the process of bone regeneration by changing the cellular response. Because of the ability to generate charge/ potential in response to mechanical deformation, nano$\mathrm{ZnO}$ piezoelectric materials exhibit promising potential in the fabrication of smart stimulation scaffolds for bone regeneration [149].

Pang et al. used a Bose dynamic biomechanical reactor to periodically load on the surface of the $\mathrm{ZnO} /$ $\mathrm{TiO}_{2}$ coating to investigate its effects on the spreading, proliferation, and differentiation of MC3T3-E1 osteoblasts. After applying periodic loading, the cell proliferation rate and the number of cell pseudopods on the coating material were increased. However, loading on the surface of $\mathrm{Ti}$ without piezoelectric effect had no significant effect on cell proliferation and differentiation compared with that without loading. Moreover, after loading, the expression of ALP on Ti surface coatings with different particle sizes of $\mathrm{nZnO} /$ $\mathrm{TiO}_{2}(\mathrm{Z} 1<\mathrm{Z2}<\mathrm{Z} 3)$ increased significantly compared with unloaded coatings; the expression of ALP on Z1, $\mathrm{Z} 2$, and $\mathrm{Z} 3$ coatings was significantly higher than that of unloaded Z1, Z2, and Z3 coatings. These results confirmed that the significant improvement in the cytocompatibility and osteogenic ability of MC3T3E1 could be attributed to the piezoelectric properties of $\mathrm{ZnO} / \mathrm{TiO}_{2}$ under the periodic loading. Besides, because the $\mathrm{Z} 1$ coating had the largest piezoelectric coefficient and produced the most charge, the highest expression of ALP was obtained. It showed the particle size of $\mathrm{ZnO} / \mathrm{TiO}_{2}$ is negatively correlated with the piezoelectric properties, cytocompatibility, and osteogenic properties of the composite coatings. Although $\mathrm{ZnO} / \mathrm{TiO}_{2}$ piezoelectric composites show good piezoelectric properties under periodic loading and can promote the activity of osteoblasts in vitro, in vivo testing of this smart biomaterial remains to be verified [108]. 


\section{Effect of nano-ZnO modified Ti implants on neovascularization formation}

It is well-known that the formation of neovascularization is extremely valuable for bone regeneration, as it promotes nutrient delivery and bone repair [150]. Thus, clinical success depends not only on the osseointegration around the Ti implant, but also on the neovascularization [16]. Various growth factors secreted by osteoblasts, e.g. vascular endothelial growth factor (VEGF), fibroblast growth factor-2 (FGF-2), and angiopoietin 1, are regulated by the morphology and energy of the Ti implant surface $[151,152]$. It was reported that $\mathrm{Zn}$ is an important component of early growth response 3 (Egr3) which has an essential downstream role in VEGF-mediated endothelial functions leading to angiogenesis [153]. Maimaiti et al. cultured VECs on the surface of the composite coating and observed that the adherence and spreading of VECs improved with the addition of nano- $\mathrm{ZnO}$ within the composite coating [61].

\section{Anti-corrosion property of nano-ZnO modified $\mathrm{Ti}$ implants}

Metals in implant devices are prone to corrosion, thereby disturbing the homeostasis of osteoblasts [154]. Corrosion of the metal layer of the implant may be due to the cracked and porous nature of the coating, which makes it permeable. Electrolytes penetrate these pores and come into contact with the substrate surface, thus initiating the corrosion process. Therefore, much research has been focused on depositing functional coatings on $\mathrm{Ti}$ substrates to improve the corrosion resistance in a simulated in vivo environment. It was frequently reported that the corrosion performance of Ti substrate materials decorated with nano- $\mathrm{ZnO}$ was significantly improved. Aydin et al. deposited nano- $\mathrm{ZnO}$ and nano- $\mathrm{Ag}$ on the surface of $\mathrm{TiO}_{2}$-nanotubes using hydrothermal and chemical reduction methods respectively, and found that the $\mathrm{ZnO}-\mathrm{TiO}_{2}$-nanotubes had a higher resistance value, i.e., higher corrosion resistance. This result was attributed to the advantage of the $\mathrm{ZnO}$ nanorods structure in blocking the $\mathrm{TiO}_{2}$ tube channel [155]. In a study, a $\mathrm{ZnO}$-doped tantalum oxide $\left(\mathrm{Ta}_{\mathrm{x}} \mathrm{O}_{\mathrm{y}}\right)$ multilayer composite coating was deposited by magnetron sputtering at room temperature. The potentiodynamic polarization curves revealed that $\mathrm{ZnO}$-doped multilayer composite coating had higher corrosion potential and lower corrosion current density $\left(1.12 \pm 0.004 \mu \mathrm{A} / \mathrm{cm}^{2}\right)$ than that of $\mathrm{Ta}_{\mathrm{x}} \mathrm{O}_{\mathrm{y}}$ coating, showing better corrosion inhibition [67]. Roknian et al. indicated that the corrosion current density had a $93 \%$ reduction for the sample containing $\mathrm{ZnO}$ nanoparticles at a concentration of $15 \mathrm{~g} / \mathrm{L}$ in comparison with the uncoated Ti substrate [58]. Similarly, the $\mathrm{TiO}_{2}$ coatings incorporated with $30 \mathrm{wt} \%$ nano- $\mathrm{ZnO}$ revealed the highest corrosion resistance and antibacterial activity due to the synergistic actions of both $\mathrm{TiO}_{2}$ and $\mathrm{ZnO}$ [156]. Besides, Vijayalakshmi et al. also made a composite coating with $\mathrm{TiO}_{2}$ and $\mathrm{ZnO}$ via an electrophoretically deposited method to enhance the activity against electrochemical corrosion. It was found that good corrosion resistance capacity was achieved at a voltage of $40 \mathrm{~V}$ sintered in a vacuum atmosphere compared to other coating conditions, which was attributed to a denser surface and less porosity [62]. Moreover, incorporation of $\mathrm{Sr}^{2+}$ and $\mathrm{ZnO}$ into HA significantly reduced porosity, and the SrHA/ZnO coating became significantly denser, which exhibits higher corrosion resistance in simulated body fluid than the pure HA coating [60]. Although it has been confirmed that nano- $\mathrm{ZnO}$ coatings could alter the corrosion performance of the original Ti substrate, differences in surface morphology with a specific chemical composition may still result in variable biological properties. Recently, it was reported that the nano- $\mathrm{ZnO}$ coating with spherical morphology provided high initial corrosion performance, while the irregular nanosheet with porous networks and flower-like morphology impaired the corrosion performance of the Ti6Al4V substrate [92].

To enhance the corrosion resistance of the nano- $\mathrm{ZnO}$ coating on a Ti substrate, nano- $\mathrm{ZnO}$ was functionalized with different bifunctional organic molecules. Electrochemical results indicated that the modification of $\mathrm{Ti}$ with nano- $\mathrm{ZnO}$ and organic molecules shifted the open circuit potentials to a higher level, decreased the corrosion current density, enhanced the resistance of the material, and significantly improved the corrosion resistance of pristine Ti. In particular, the APPA bifunctional molecule modified with $\mathrm{ZnO}$, showed high surface energy, noble open-circuit potential $(-0.2 \mathrm{~V})$ and significantly lower corrosion current density $\left(5.3 \times 10^{-7} \mathrm{~A} / \mathrm{cm}^{2}\right)$, indicating promising interactions with bioactive molecules in the biological environment and improved corrosion resistance [71], which was confirmed in another study [72]. In summary, factors such as preparation parameters and composition ratios may have an impact on corrosion resistance and remain to be further explored. In fact, since the body environment is extremely complex and variable, electrochemical experiments only indicate a trend in corrosion resistance of Ti implants, while the actual period of effective corrosion resistance in clinical use has to be assessed by extensive animal studies in vivo.

\section{Conclusion and perspectives}

Ti is widely used in human implants due to its good biocompatibility and suitable mechanical strength, but its surface oxidation susceptibility leads to biological inertia that limits its practical use. To solve this issue, one of the hot research topics in recent years is the surface 
modification of implants to obtain the desired properties. Among various materials, nano- $\mathrm{ZnO}$ is considered to be a broad-spectrum inorganic antimicrobial agent with a good bactericidal effect against almost all known bacteria, and zinc is one of the essential trace elements in the human body. This review focused on methods for nano-ZnO modification of the surface of Ti substrates, possible antimicrobial mechanisms of nano- $\mathrm{ZnO}$, as well as antimicrobial applications of nano- $\mathrm{ZnO}$ and $\mathrm{Ti}$ substrate surfaces with two or more composites containing nano- $\mathrm{ZnO}$. In addition, the application of nano$\mathrm{ZnO}$ in osteogenesis induction was discussed. Finally, a summary of the enhanced anti-corrosion properties of nano- $\mathrm{ZnO}$ was presented. The purpose of this review was to provide a reliable reference for scientists and clinicians interested in the functional applications of $\mathrm{ZnO}$-nanomaterials on Ti surfaces by summarizing and discussing their applications in recent years.

Surface modification is a useful strategy for enhancing the biological properties of the Ti substrate. Now, it is considered as a central concept to develop modified $\mathrm{Ti}$ materials that are clinic-driven based on the characteristics of the patient's course of the process. Nano- $\mathrm{ZnO}$ modified Ti-based materials have presented satisfactory (bio)physicochemical performances in current studies relevant to resistance to bacterial infection, while the cytotoxic phenomenon exhibited in some studies will necessitate a focus on balancing antimicrobial and biocompatibility in future research. Possible research hotspots involve exploring the minimum amount of nano- $\mathrm{ZnO}$ to inhibit bacteria on specific platform surfaces, developing smart release modes triggered upon infection, improving or exploring novel hybrid coatings and their potential antimicrobial mechanisms to reduce reliance on the original mechanisms. With the clinical requirements for slow corrosion rates and prolonged stability of the implant, changes in the integrity of the nano-ZnO-modified coating during in vivo degradation are modeled by in vitro experiments with appropriate simulated body fluid, and subsequent long-term experiments in vivo to verify and assess the osseointegration stability. In fact, nano- $\mathrm{ZnO}$ is comparatively rare in the literature for modified $\mathrm{Ti}$ compared to other conventional materials (Ag, HA, organic materials, etc.) and even scarcer for in vivo studies. More importantly, the implant material is considered a foreign invader and the body's immune system plays an extremely important role in fighting it. In this context, the available scientific literatures have not been discussed from a comprehensive perspective. Therefore, it is necessary to construct sophisticated microenvironmental models of the human body to explore in-depth the biological changes and the underlying mechanisms that occur with various types of cells and tissues after implantation under immune response. These approaches will facilitate the design of a multifunctional nanomaterial platform for superior bio-implant materials that are efficiently resistant to bacterial infection and provide improved osseointegration efficiency, while maintaining biocompatibility or low cytotoxicity.

\section{Acknowledgements \\ Not applicable.}

\section{Authors' contributions}

ZW: Writing-original draft. XW: Writing-review and editing. YW: Writing-review and editing. YZ: Visualization. XL: Conceptualization, Writing-review and editing. QZ: Conceptualization, Writing-review and editing, Project administration. All authors read and approved the final manuscript.

\section{Funding}

The authors are very grateful for financial support of by the National Natural Science Foundation of China (Grant No. 31900957), Shandong Provincial Natural Science Foundation (Grant No. ZR2019QC007), Innovation and technology program for the excellent youth scholars of higher education of Shandong province (Grant No. 2019KJE015), Traditional Chinese Medicine Science and Technology Project of Shandong Province (Grant No. 2021Q069), and China Postdoctoral Science Foundation (Grant No. 2019M652326).

Availability of data and materials

Without restrictions.

\section{Declarations}

Ethics approval and consent to participate

Not applicable.

\section{Consent for publication}

All authors gave their consent for publication.

\section{Competing interests}

The authors declare that they have no competing interests.

\section{Author details}

${ }^{1}$ Institute for Translational Medicine, Department of Orthodontics, The Affiliated Hospital of Qingdao University, Qingdao University, Qingdao 266003, China. ${ }^{2}$ School of Stomatology, Qingdao University, Qingdao 266003, China. ${ }^{3}$ Department of Oral Implantology, The Affiliated Hospital of Qingdao University, Qingdao 266003, China. ${ }^{4}$ Shandong University of Science and Technology, Qingdao 266590, China.

Received: 23 August 2021 Accepted: 20 October 2021

Published online: 30 October 2021

$$
\begin{aligned}
& \text { References } \\
& \text { 1. Yang H, Jia B, Zhang Z, Qu X, Li G, Lin W, et al. Alloying design of biode- } \\
& \text { gradable zinc as promising bone implants for load-bearing applica- } \\
& \text { tions. Nat Commun. 2020;11:401. } \\
& \text { 2. Kandavalli SR, Wang Q, Ebrahimi M, Gode C, Djavanroodi F, Attarilar S, } \\
& \text { et al. A Brief Review on the Evolution of Metallic Dental Implants: His- } \\
& \text { tory, Design, and Application. Front Mater. 2021;8:646383. } \\
& \text { 3. Kumari S, Tiyyagura HR, Pottathara YB, Sadasivuni KK, Ponnamma D, } \\
& \text { Douglas TEL, et al. Surface functionalization of chitosan as a coating } \\
& \text { material for orthopaedic applications: A comprehensive review. Carbo- } \\
& \text { hydr Polym. 2021;255:117487. } \\
& \text { 4. Zhang E, Zhao X, Hu J, Wang R, Fu S, Qin G. Antibacterial metals and } \\
& \text { alloys for potential biomedical implants. Bioact Mater. 2021;6:2569-612. }
\end{aligned}
$$


5. Mokabber T, Zhou Q, Vakis Al, van Rijn P, Pei YT. Mechanical and biological properties of electrodeposited calcium phosphate coatings. Mater Sci Eng C. 2019;100:475-84.

6. Basova TV, Vikulova ES, Dorovskikh SI, Hassan A, Morozova NB. The use of noble metal coatings and nanoparticles for the modification of medical implant materials. Mater Des. 2021;204:109672.

7. Arciola CR, Campoccia D, Montanaro L. Implant infections: Adhesion, biofilm formation and immune evasion. Nat Rev Microbiol. 2018:16:397-409.

8. Wu S, Xu J, Zou L, Luo S, Yao R, Zheng B, et al. Long-lasting renewable antibacterial porous polymeric coatings enable titanium biomaterials to prevent and treat peri-implant infection. Nat Commun. 2021;12:3303.

9. Yuan Z, He Y, Lin C, Liu P, Cai K. Antibacterial surface design of biomedical titanium materials for orthopedic applications. J Mater Sci Technol. 2021;78:51-67.

10. Wang Z, Niu Y, Tian X, Yu N, Yin X, Xing Z, et al. Switching on and off macrophages by a "bridge-burning" coating improves bone-implant integration under osteoporosis. Adv Funct Mater. 2021;31:2007408.

11. Darouiche RO. Treatment of infections associated with surgical implants. N Engl J Med. 2004:350:1422-9.

12. Mahamuni-Badiger PP, Patil PM, Badiger MV, Patel PR, Thorat-Gadgil BS, Pandit A, et al. Biofilm formation to inhibition: role of zinc oxide-based nanoparticles. Mater Sci Eng C. 2020;108:110319.

13. Montanaro L, Speziale P, Campoccia D, Ravaioli S, Cangini I, Pietrocola $\mathrm{G}$, et al. Scenery of Staphylococcus implant infections in orthopedics. Future Microbiol. 2011;6:1329-49.

14. Arciola CR, Campoccia D, Ehrlich GD, Montanaro L. Biofilm-based implant infections in orthopaedics. In: Biofilm-based Healthcare-associated Infections. 2015. p. 29-46.

15. Chen J, Hendriks M, Chatzis A, Ramasamy SK, Kusumbe AP. Bone Vasculature and Bone Marrow Vascular Niches in Health and Disease. J Bone Miner Res. 2020;35:2103-20.

16. Xu N, Fu J, Zhao L, Chu PK, Huo K. Biofunctional Elements Incorporated Nano/Microstructured Coatings on Titanium Implants with Enhanced Osteogenic and Antibacterial Performance. Adv Healthc Mater. 2020;9:2000681.

17. Keceli HG, Bayram C, Celik E, Ercan N, Demirbilek M, Nohutcu RM. Dual delivery of platelet-derived growth factor and bone morphogenetic factor- 6 on titanium surface to enhance the early period of implant osseointegration. J Periodontal Res. 2020;55:694-704.

18. Wang Z, Mei L, Liu X, Zhou Q. Hierarchically hybrid biocoatings on Ti implants for enhanced antibacterial activity and osteogenesis. Colloids Surfaces B Biointerfaces. 2021;204:111802.

19. Yang WE, Huang $\mathrm{HH}$. Multiform $\mathrm{TiO}_{2}$ nano-network enhances biological response to titanium surface for dental implant applications. Appl Surf Sci. 2019:471:1041-52.

20. Branemark PI. Osseointegration and its experimental background. J Prosthet Dent. 1983;50:399-410.

21. Yang L, Pijuan-Galito S, Rho HS, Vasilevich AS, Eren AD, Ge L, et al. HighThroughput Methods in the Discovery and Study of Biomaterials and Materiobiology. Chem Rev. 2021;121:4561-677.

22. Zhang $Q$, Ji Y, Zheng W, Yan M, Wang D, Li M, et al. Electrospun nanofibers containing strontium for bone tissue engineering. J Nanomater. 2020;2020:1257646.

23. Bao M, Lou X, Zhou Q, Dong W, Yuan H, Zhang Y. Electrospun biomimetic fibrous scaffold from shape memory polymer of PDLLACO -TMC for bone tissue engineering. ACS Appl Mater Interfaces. 2014;6:2611-21.

24. Lee JW, Wen HB, Gubbi P, Romanos GE. New bone formation and trabecular bone microarchitecture of highly porous tantalum compared to titanium implant threads: A pilot canine study. Clin Oral Implants Res. 2018:29:164-74.

25. Wu S, Liu X, Yeung KWK, Guo H, Li P, Hu T, et al. Surface nano-architectures and their effects on the mechanical properties and corrosion behavior of Ti-based orthopedic implants. Surf Coatings Technol. 2013:233:13-26.

26. Gruber R. Cell biology of osteoimmunology. Wien Med Wochenschr. 2010;160:438-45.

27. Arron JR, Choi Y. Bone versus immune system. Nature. 2000;408:535-6.

28. Xia Z, Triffitt JT. A review on macrophage responses to biomaterials. Biomed Mater. 2006:1:1-9.
29. Lugowski SJ, Smith DC, McHugh AD, Van Loon JC. Release of metal ions from dental implant materials in vivo: Determination of $\mathrm{Al}, \mathrm{Co}, \mathrm{Cr}, \mathrm{Mo}$, $\mathrm{Ni}, \mathrm{V}$, and Ti in organ tissue. J Biomed Mater Res. 1991;25:1443-58.

30. Chouirfa H, Bouloussa H, Migonney V, Falentin-Daudré C. Review of titanium surface modification techniques and coatings for antibacterial applications. Acta Biomater. 2019;83:37-54.

31. Kreyling WG, Semmler-Behnke M, Chaudhry Q. A complementary definition of nanomaterial. Nano Today. 2010;5:165-8.

32. Zheng W, Zhou Q, Yuan C. Nanoparticles for oral cancer diagnosis and therapy. Bioinorg Chem Appl. 2021;2021:9977131.

33. Liu L, Han Z, An F, Gong X, Zhao C, Zheng W, et al. Aptamer-based biosensors for the diagnosis of sepsis. J Nanobiotechnology. 2021;19:1-22.

34. Ji Y, Han Z, Ding H, Xu X, Wang D, Zhu Y, et al. Enhanced Eradication of Bacterial/Fungi Biofilms by Glucose Oxidase-Modified Magnetic Nanoparticles as a Potential Treatment for Persistent Endodontic Infections. ACS Appl Mater Interfaces. 2021;13:17289-99.

35. Zhou Q, Zhao Z, Zhou Z, Zhang G, Chiechi RC, van Rijn P. Directing Mesenchymal Stem Cells with Gold Nanowire Arrays. Adv Mater Interfaces. 2018:5:1-8.

36. Liu XF, Zhang J, Liu JJ, Zhou QH, Liu Z, Hu PY, et al. Bifunctional CuS composite nanofibers via in situ electrospinning for outdoor rapid hemostasis and simultaneous ablating superbug. Chem Eng J. 2020;401:126096.

37. Liu Y, Busscher HJ, Zhao B, Li Y, Zhang Z, van der Mei HC, et al. Surfaceadaptive, antimicrobially loaded, micellar nanocarriers with enhanced penetration and killing efficiency in staphylococcal biofilms. ACS Nano. 2016;10:4779-89.

38. Liu Y, Shi L, Su L, van der Mei HC, Jutte PC, Ren Y, et al. Nanotechnologybased antimicrobials and delivery systems for biofilm-infection control. Chem Soc Rev. 2019;48:428-46.

39. Liu Y, Ren Y, Li Y, Su L, Zhang Y, Huang F, et al. Nanocarriers with conjugated antimicrobials to eradicate pathogenic biofilms evaluated in murine in vivo and human ex vivo infection models. Acta Biomater. 2018;79:331-43.

40. Li M, Deng W, Zhang J, Zheng W, Yu T, Zhou Q. Aligned Electrospun PLLA/Graphene Microfibers with Nanotopographical Surface Modulate the Mitochondrial Responses of Vascular Smooth Muscle Cells. Adv Mater Interfaces. 2021:8:2100229.

41. Qiu X, Xu S, Hao Y, Peterson B, Li B, Yang K, et al. Biological effects on tooth root surface topographies induced by various mechanical treatments. Colloids Surfaces B Biointerfaces. 2020;188:110748.

42. Yu Z, Li Q, Wang J, Yu Y, Wang Y, Zhou Q, et al. Reactive Oxygen SpeciesRelated Nanoparticle Toxicity in the Biomedical Field. Nanoscale Res Lett. 2020;15:115.

43. Zhu X, Radovic-Moreno AF, Wu J, Langer R, Shi J. Nanomedicine in the management of microbial infection-Overview and perspectives. Nano Today. 2014;9:478-98

44. Vargas-Reus MA, Memarzadeh K, Huang J, Ren GG, Allaker RP. Antimicrobial activity of nanoparticulate metal oxides against peri-implantitis pathogens. Int J Antimicrob Agents. 2012;40:135-9.

45. Xie K, Zhou Z, Guo Y, Wang L, Li G, Zhao S, et al. Long-Term Prevention of Bacterial Infection and Enhanced Osteoinductivity of a Hybrid Coating with Selective Silver Toxicity. Adv Healthc Mater. 2019:8:1-12.

46. Zhang Y, Liu X, Li Z, Zhu S, Yuan X, Cui Z, et al. Nano Ag/ZnO-Incorporated Hydroxyapatite Composite Coatings: Highly Effective Infection Prevention and Excellent Osteointegration. ACS Appl Mater Interfaces. 2018:10:1266-77.

47. Zhang R, Liu X, Xiong Z, Huang Q, Yang X, Yan H, et al. Novel micro/ nanostructured $\mathrm{TiO}_{2} / \mathrm{ZnO}$ coating with antibacterial capacity and cytocompatibility. Ceram Int. 2018:44:9711-9.

48. Wu X, Yao L, Al-Baadani MA, Ping L, Wu S, Al-Bishari AM, et al. Preparation of multifunctional drug sustained-release system by atomic layer deposition of $\mathrm{ZnO}$ in mesoporous titania coating. Ceram Int. 2020:46:9406-14.

49. Teow Y, Asharani PV, Hande MP, Valiyaveettil S. Health impact and safety of engineered nanomaterials. Chem Commun. 2011:47:7025-38.

50. Sirelkhatim A, Mahmud S, Seeni A, Kaus NHM, Ann LC, Bakhori SKM, et al. Review on zinc oxide nanoparticles: Antibacterial activity and toxicity mechanism. Nano-Micro Lett. 2015;7:219-42. 
51. Hu H, Zhang W, Qiao Y, Jiang X, Liu X, Ding C. Antibacterial activity and increased bone marrow stem cell functions of $\mathrm{Zn}$-incorporated $\mathrm{TiO}_{2}$ coatings on titanium. Acta Biomater. 2012;8:904-15.

52. Zhu Y, Liu X, Yeung KWK, Chu PK, Wu S. Biofunctionalization of carbon nanotubes/chitosan hybrids on Ti implants by atom layer deposited ZnO nanostructures. Appl Surf Sci. 2017;400:14-23.

53. Zhang $R$, Liu X, Xiong Z, Huang Q, Yang X, Yan H, et al. The immunomodulatory effects of $\mathrm{Zn}$-incorporated micro/nanostructured coating in inducing osteogenesis. Artif Cells Nanomedicine Biotechnol. 2018:46:1123-30.

54. Roguska A, Belcarz A, Pisarek M, Ginalska G, Lewandowska M. TiO, nanotube composite layers as delivery system for $\mathrm{ZnO}$ and $\mathrm{Ag}$ nanoparticles - An unexpected overdose effect decreasing their antibacterial efficacy. Mater Sci Eng C. 2015;51:158-66.

55. Chu CL, Liu ZH, Rao X, Sun Q, Lin PH, Chen F, et al. Micro-nano hierarchical porous titania modified with ZnO nanorods for biomedical applications. Surf Coatings Technol. 2013;232:68-74.

56. Yao S, Feng X, Lu J, Zheng Y, Wang X, Volinsky AA, et al. Antibacterial activity and inflammation inhibition of $\mathrm{ZnO}$ nanoparticles embedded $\mathrm{TiO}_{2}$ nanotubes. Nanotechnology. 2018;29:244003.

57. Chang YY, Lai CH, Hsu JT, Tang CH, Liao WC, Huang HL. Antibacterial properties and human gingival fibroblast cell compatibility of $\mathrm{TiO}_{2} / \mathrm{Ag}$ compound coatings and $\mathrm{ZnO}$ films on titanium-based material. Clin Oral Investig. 2012;16:95-100.

58. Roknian M, Fattah-alhosseini A, Gashti SO, Keshavarz MK. Study of the effect of $\mathrm{ZnO}$ nanoparticles addition to PEO coatings on pure titanium substrate: Microstructural analysis, antibacterial effect and corrosion behavior of coatings in Ringer's physiological solution. J Alloys Compd. 2018;740:330-45.

59. Yin L, Fu Z, Li Y, Liu B, Lin Z, Lu J, et al. Enhanced antibacterial properties of biocompatible titanium via electrochemically deposited $\mathrm{Ag} / \mathrm{TiO}$ nanotubes and chitosan-gelatin-Ag-ZnO complex coating. RSC Adv. 2019:9:4521-9.

60. Huang $Y$, Zeng $H$, Wang $X$, Wang D. Corrosion resistance and biocompatibility of $\mathrm{SrHAp} / \mathrm{ZnO}$ composite implant coating on titanium. Appl Surf Sci. 2014;290:353-8.

61. Maimaiti B, Zhang N, Yan L, Luo J, Xie C, Wang Y, et al. Stable ZnOdoped hydroxyapatite nanocoating for anti-infection and osteogenic on titanium. Colloids Surfaces B Biointerfaces. 2020;186:110731.

62. Vijayalakshmi U, Chellappa M, Anjaneyulu U, Manivasagam G, Sethu S. Influence of Coating Parameter and Sintering Atmosphere on the Corrosion Resistance Behavior of Electrophoretically Deposited Composite Coatings. Mater Manuf Process. 2016;31:95-106.

63. Koie S, Asakura M, Hasegawa S, Hayashi T, Kawai T, Nagao T. Proliferation of mouse fibroblasts and osteoblastic cells on $\mathrm{ZrO}_{2}-, \mathrm{SiO}_{2}-$, and $\mathrm{ZnO}$ deposited pure titanium discs using atomic layer deposition. Mater Lett. 2021;303:130525.

64. Zhang K, Zhu Y, Liu X, Cui Z, Xianjin Y, Yeung KWK, et al. Sr/ZnO doped titania nanotube array: An effective surface system with excellent osteoinductivity and self-antibacterial activity. Mater Des. 2017;130:403-12.

65. Li J, Tan L, Liu X, Cui Z, Yang X, Yeung KWK, et al. Balancing BacteriaOsteoblast Competition through Selective Physical Puncture and Biofunctionalization of $\mathrm{ZnO} /$ Polydopamine/Arginine-Glycine-Aspartic Acid-Cysteine Nanorods. ACS Nano. 2017;1 1:11250-63.

66. Wang J, Zhou H, Guo G, Tan J, Wang Q, Tang J, et al. Enhanced AntiInfective Efficacy of ZnO Nanoreservoirs through a Combination of Intrinsic Anti-Biofilm Activity and Reinforced Innate Defense. ACS Appl Mater Interfaces. 2017:9:33609-23.

67. Ding Z, He Q, Ding Z, Liao C, Chen D, Ou L. Fabrication and performance of $\mathrm{ZnO}$ doped tantalum oxide multilayer composite coatings on TI6AL4V for orthopedic application. Nanomaterials. 2019;9:685.

68. Shih CY, Gnilitskyi I, Shugaev MV, Skoulas E, Stratakis E, Zhigilei LV. Effect of a liquid environment on single-pulse generation of laser induced periodic surface structures and nanoparticles. Nanoscale. 2020;12:7674-87.

69. Zhao Z, Wan Y, Yu M, Wang H, Cai Y, Liu C, et al. Biocompability evaluation of micro textures coated with zinc oxide on Ti-6Al-4V treated by nanosecond laser. Surf Coatings Technol. 2021;422:127453.

70. Abdulkareem EH, Memarzadeh K, Allaker RP, Huang J, Pratten J, Spratt D. Anti-biofilm activity of zinc oxide and hydroxyapatite nanoparticles as dental implant coating materials. J Dent. 2015;43:1462-9.
71. Trino LD, Dias LFG, Albano LGS, Bronze-Uhle ES, Rangel EC, Graeff CFO, et al. Zinc oxide surface functionalization and related effects on corrosion resistance of titanium implants. Ceram Int. 2018;44:4000-8.

72. Trino LD, Albano LGS, Bronze-Uhle ES, George A, Mathew MT, LisboaFilho PN. Physicochemical, osteogenic and corrosion properties of bio-functionalized $\mathrm{ZnO}$ thin films: Potential material for biomedical applications. Ceram Int. 2018;44:21004-14.

73. Fu T, Zhang F, Alajmi Z, Yang SY, Wu F, Han SL. Sol-gel derived antibacterial Ag-containing $\mathrm{ZnO}$ films on biomedical titanium. J Nanosci Nanotechnol. 2018;18:823-8.

74. Liu W, Su P, Gonzales A, Chen S, Wang N, Wang J, et al. Optimizing stem cell functions and antibacterial properties of $\mathrm{TiO}_{2}$ nanotubes incorporated with $\mathrm{ZnO}$ nanoparticles: Experiments and modeling. Int J Nanomedicine. 2015:10:1997-2019.

75. Gunputh UF, Le H, Besinis A, Tredwin C, Handy RD. Multilayered composite coatings of titanium dioxide nanotubes decorated with zinc oxide and hydroxyapatite nanoparticles: Controlled release of Zn and antimicrobial properties against staphylococcus aureus. Int J Nanomedicine. 2019;14:3583-600.

76. Xiang Y, Li J, Liu X, Cui Z, Yang X, Yeung KWK, et al. Construction of poly(lactic-co-glycolic acid)/ZnO nanorods/Ag nanoparticles hybrid coating on Ti implants for enhanced antibacterial activity and biocompatibility. Mater Sci Eng C. 2017;79:629-37.

77. Shang J, Sun Y, Zhang T, Liu Z, Zhang H. Enhanced antibacterial activity of Ag nanoparticle-decorated $\mathrm{ZnO}$ nanorod arrays. J Nanomater. 2019;2019:3281802.

78. Li Y, Liu X, Tan L, Cui Z, Yang X, Yeung KWK, et al. Construction of $\mathrm{N}$-halamine labeled silica/zinc oxide hybrid nanoparticles for enhancing antibacterial ability of Ti implants. Mater Sci Eng C. 2017;76:50-8.

79. Wang X, Fan H, Zhang F, Zhao S, Liu Y, Xu Y, et al. Antibacterial Properties of Bilayer Biomimetic Nano-ZnO for Dental Implants. ACS Biomater Sci Eng. 2020;6:1880-6.

80. Lin MH, Wang $Y H$, Kuo CH, Ou SF, Huang PZ, Song TY, et al. Hybrid $\mathrm{ZnO} /$ chitosan antimicrobial coatings with enhanced mechanical and bioactive properties for titanium implants. Carbohydr Polym. 2021:257:117639.

81. Xiang Y, Liu X, Mao C, Liu X, Cui Z, Yang $X$, et al. Infection-prevention on Ti implants by controlled drug release from folic acid/ZnO quantum dots sealed titania nanotubes. Mater Sci Eng C. 2018;85 August 2017:214-24

82. Ohtsu N, Kakuchi Y, Ohtsuki T. Antibacterial effect of zinc oxide/ hydroxyapatite coatings prepared by chemical solution deposition. Appl Surf Sci. 2018;445:596-600.

83. Liao H, Miao X, Ye J, Wu T, Deng Z, Li C, et al. Falling Leaves Inspired ZnO Nanorods-Nanoslices Hierarchical Structure for Implant Surface Modification with Two Stage Releasing Features. ACS Appl Mater Interfaces. 2017:9:13009-15.

84. Hao Y, Zheng W, Sun Z, Zhang D, Sui K, Shen P, et al. Marine polysaccharide-based composite hydrogels containing fucoidan: Preparation, physicochemical characterization, and biocompatible evaluation. Int J Biol Macromol. 2021:183:1978-86.

85. Yin $X$, Hao Y, Lu Y, Zhang D, Zhao Y, Mei L, et al. Bio-Multifunctional Hydrogel Patches for Repairing Full-Thickness Abdominal Wall Defect. Adv Funct Mater. 2021;31:2105614.

86. Taccola L, Raffa V, Riggio C, Vittorio O, lorio MC, Vanacore R, et al. Zinc oxide nanoparticles as selective killers of proliferating cells. Int J Nanomedicine. 2011;6:1129-40.

87. Vicario-Parés U, Castañaga L, Lacave JM, Oron M, Reip P, Berhanu $\mathrm{D}$, et al. Comparative toxicity of metal oxide nanoparticles (CuO, $\mathrm{ZnO}$ and $\mathrm{TiO}_{2}$ ) to developing zebrafish embryos. J Nanoparticle Res. 2014;16:2550.

88. Li Y, Yang Y, Qing Y, Li R, Tang X, Guo D, et al. Enhancing ZnO-NP Antibacterial and Osteogenesis Properties in Orthopedic Applications: A Review. Int J Nanomedicine. 2020:15:6247-62.

89. Lee J, Kang BS, Hicks B, Chancellor TF, Chu BH, Wang HT, et al. The control of cell adhesion and viability by zinc oxide nanorods. Biomaterials. 2008;29:3743-9.

90. Qi H, Yang L, Shan P, Zhu S, Ding H, Xue S, et al. The stability maintenance of protein drugs in organic coatings based on nanogels. Pharmaceutics. 2020;12:115. 
91. Luo J, Mamat B, Yue Z, Zhang N, Xu X, Li Y, et al. Multi-metal ions doped hydroxyapatite coatings via electrochemical methods for antibacterial and osteogenesis. Colloids Interface Sci Commun. 2021;43:100435.

92. Saidi R, Raeissi K, Ashrafizadeh F, Kharaziha M. The effect of zinc oxide coating morphology on corrosion performance of Ti-6Al-4V alloys. J Alloys Compd. 2021;883:160771.

93. Besinis A, Tredwin C, Handy RD. Multilayered composite coatings of titanium dioxide nanotubes decorated with zinc oxide and hydroxyapatite nanoparticles: controlled release of $\mathrm{Zn}$ and antimicrobial properties against Staphylococcus aureus. Bmc. 2019;14:3583-600.

94. Tian C, Yang Y, Bai B, Wang S, Liu M, Sun RC, et al. Potential of exosomes as diagnostic biomarkers and therapeutic carriers for doxorubicininduced cardiotoxicity. Int J Biol Sci. 2021;17:1328-38.

95. Jiang M, Zhang J, Qian L, Miao Y, Song W, Liu H, et al. MOZ Forms an Autoregulatory Feedback Loop with miR-223 in AML and Monocyte/ Macrophage Development. iScience. 2019;11:189-204.

96. Huang Z, Zheng X, Yan D, Yin G, Liao X, Kang Y, et al. Toxicological effect of ZnO nanoparticles based on bacteria. Langmuir. 2008;24:4140-4.

97. Zhao WB, Du MR, Liu KK, Zhou R, Ma RN, Jiao Z, et al. Hydrophilic ZnO Nanoparticles@Calcium Alginate Composite for Water Purification. ACS Appl Mater Interfaces. 2020;12:13305-15.

98. Qi H, Wang Y, Fa S, Yuan C, Yang L. Extracellular Vesicles as Natural Delivery Carriers Regulate Oxidative Stress Under Pathological Conditions. Front Bioeng Biotechnol. 2021;9:752019.

99. Bagchi D, Rathnam VSS, Lemmens P, Banerjee I, Pal SK. NIR-Light-Active ZnO-Based Nanohybrids for Bacterial Biofilm Treatment. ACS Omega. 2018;3:10877-85.

100. Jeong E, UI C, Byun J, Lee J, Kim H, Kim E, et al. Science of the Total Environment Quantitative evaluation of the antibacterial factors of $\mathrm{ZnO}$ nanorod arrays under dark conditions: Physical and chemical effects on Escherichia coli inactivation. Sci Total Environ. 2020;712:136574.

101. Ahmed B, Musarrat J. ZnONPs uptake and nanocolloid-bacteria interface Bacterial toxicity of biomimetic green zinc oxide nanoantibiotic: insights into ZnONP uptake and nanocolloid - bacteria interface. Toxicol Res (Camb). 2018:8:246-61.

102. Jiang $Y$, Zhang $L$, Wen D, Ding Y. Role of physical and chemical interactions in the antibacterial behavior of $\mathrm{ZnO}$ nanoparticles against $\mathrm{E}$. coli. Mater Sci Eng C. 2016;69:1361-6.

103. Xie $Y$, He Y, Irwin PL, Jin T, Shi X. Antibacterial activity and mechanism of action of zinc oxide nanoparticles against Campylobacter jejuni. Appl Environ Microbiol. 2011;77:2325-31.

104. Reddy LS, Nisha MM, Joice M, Shilpa PN, Shalini L, Nisha MM, et al. Antimicrobial activity of zinc oxide $(\mathrm{ZnO})$ nanoparticle against Klebsiella pneumoniae Antimicrobial activity of zinc oxide $(\mathrm{ZnO})$ nanoparticle against Klebsiella pneumoniae. Pharm Biol. 2014;52:1388-97.

105. Xue S, Zhang T, Wang X, Zhang Q, Huang S, Zhang L, et al. Cu, Zn Dopants Boost Electron Transfer of Carbon Dots for Antioxidation. Small. 2021:17:2102178.

106. Wang Y, Cao A, Jiang Y, Zhang X, Liu J, Liu Y. Superior Antibacterial Activity of Zinc Oxide/Graphene Oxide Composites Originating from High Zinc Concentration Localized around Bacteria. ACS Appl Mater Interfaces. 2014;6:2791-8.

107. Pal S, Tak YK, Song JM. Does the antibacterial activity of silver nanoparticles depend on the shape of the nanoparticle? A study of the gram-negative bacterium Escherichia coli. Appl Environ Microbiol. 2007;73:1712-20

108. Pang S, He Y, Zhong R, Guo Z, He P, Zhou C, et al. Multifunctional ZnO/ $\mathrm{TiO}_{2}$ nanoarray composite coating with antibacterial activity, cytocompatibility and piezoelectricity. Ceram Int. 2019;45:12663-71.

109. Sirelkhatim A, Mahmud S, Seeni A. Review on Zinc Oxide Nanoparticles: Antibacterial Activity and Toxicity Mechanism. Nano-Micro Lett. 2015;7:219-42.

110. Zhang $L$, Jiang $Y$, Ding $Y$, Povey $M$, York D. Investigation into the antibacterial behaviour of suspensions of $\mathrm{ZnO}$ nanoparticles ( $\mathrm{ZnO}$ nanofluids). J Nanoparticle Res. 2007:9:479-89.

111. Chen Q, LiT, Gui M, Liu S, Zheng M, Ni J. Bioresource Technology Effects of $\mathrm{ZnO}$ nanoparticles on aerobic denitrification by strain Pseudomonas stutzeri PCN-1. Bioresour Technol. 2017:239:21-7.

112. Brayner R, Ferrari-iliou R, Brivois N, Djediat S, Benedetti MF, Fie F, et al. Toxicological Impact Studies Based on Escherichia coli
Bacteria in Ultrafine ZnO Nanoparticles Colloidal Medium. NANO Lett. 2006;6:866-70.

113. Stoimenov PK, Klinger RL, Marchin GL, Klabunde KJ. Metal Oxide Nanoparticles as Bactericidal Agents. Langmuir. 2002;18:6679-86.

114. Mehmood S, Rehman MA, Ismail H, Mirza B, Bhatti AS. Significance of postgrowth processing of $\mathrm{ZnO}$ nanostructures on antibacterial activity against gram-positive and gram-negative bacteria. Int J Nanomedicine. 2015;10:4521-33.

115. Roguska A, Belcarz A, Suchecki P, Andrzejczuk M, Lewandowska M. Antibacterial composite layers on Ti: Role of ZnO nanoparticles. Arch Metall Mater. 2016;61:937-40.

116. Nair S, Sasidharan A, Divya Rani V, Menon D, Nair S, Manzoor K, et al. Role of size scale of $\mathrm{ZnO}$ nanoparticles and microparticles on toxicity toward bacteria and osteoblast cancer cells. J Mater Sci Mater Med. 2009;20:235-41.

117. Gabriel Colon, Brian C. Ward TJW. Increased osteoblast and decreased Staphylococcus epidermidis functions on nanophase $\mathrm{ZnO}$ and $\mathrm{TiO}_{2}$. J Biomed Mater Res Part A. 2006;78A:595-604.

118. Talebian N, Amininezhad SM, Doudi M. Controllable synthesis of ZnO nanoparticles and their morphology-dependent antibacterial and optical properties. J Photochem Photobiol B Biol. 2013;120:66-73.

119. Ivanova EP, Hasan J, Webb HK, Gervinskas G, Juodkazis S, Truong VK, et al. Bactericidal activity of black silicon. Nat Commun. 2013;4:2838.

120. Perez RA, Choi SJ, Han CM, Kim JJ, Shim H, Leong KW, et al. Biomaterials control of pluripotent stem cell fate for regenerative therapy. Prog Mater Sci. 2016;82:234-93.

121. Stevens MM, George $\mathrm{JH}$. Exploring and engineering the cell surface interface. Science. 2005;310:1135-8.

122. Xie CM, Lu X, Wang KF, Meng FZ, Jiang O, Zhang HP, et al. Silver nanoparticles and growth factors incorporated hydroxyapatite coatings on metallic implant surfaces for enhancement of osteoinductivity and antibacterial properties. ACS Appl Mater Interfaces. 2014;6:8580-9.

123. Da Silva Domingues JF, Roest S, Wang Y, Van Der Mei HC, Libera M, Van Kooten TG, et al. Macrophage phagocytic activity toward adhering staphylococci on cationic and patterned hydrogel coatings versus common biomaterials. Acta Biomater. 2015;18:1-8.

124. Aderem A, Underhill DM. Mechanisms of Phagocytosis in Macrophages. Annu Rev Immunol. 1999:17:593-623.

125. Eckhardt A, Harorli T, Limtanyakul J, Hiller KA, Bosl C, Bolay C, et al. Inhibition of cytokine and surface antigen expression in LPS-stimulated murine macrophages by triethylene glycol dimethacrylate. Biomaterials. 2009:30:1665-74.

126. Zhu Y, Liu L, Sun Z, Ji Y, Wang D, Mei L, et al. Fucoidan as a marine-origin prebiotic modulates the growth and antibacterial ability of Lactobacillus rhamnosus. Int J Biol Macromol. 2021;180:599-607.

127. Zheng W, Hao Y, Wang D, Huang H, Guo F, Sun Z, et al. Preparation of triamcinolone acetonide-loaded chitosan/fucoidan hydrogel and its potential application as an oral mucosa patch. Carbohydr Polym. 2021:272:118493.

128. Bistolfi A, Massazza G, Verné E, Massè A, Deledda D, Ferraris S, et al. Antibiotic-Loaded Cement in Orthopedic Surgery: A Review. ISRN Orthop. 2011;2011:1-8.

129. Xie C, Li P, Liu Y, Luo F, Xiao X. Preparation of $\mathrm{TiO}_{2}$ nanotubes/ mesoporous calcium silicate composites with controllable drug release. Mater Sci Eng C. 2016:67:433-9.

130. Yang L, Han D, Zhan Q, Li X, Shan P, Hu Y, et al. Blood TfR+ exosomes separated by a $\mathrm{pH}$-responsive method deliver chemotherapeutics for tumor therapy. Theranostics. 2019;9:7680-96.

131. Li Y, Liu X, Li B, Zheng Y, Han Y, Chen DF, et al. Near-Infrared Light Triggered Phototherapy and Immunotherapy for Elimination of MethicillinResistant Staphylococcus aureus Biofilm Infection on Bone Implant. ACS Nano. 2020;14:8157-70.

132. Chen G, Shen Y, Li X, Jiang Q, Cheng S, Gu Y, et al. The endoplasmic reticulum stress inducer thapsigargin enhances the toxicity of $\mathrm{ZnO}$ nanoparticles to macrophages and macrophage-endothelial co-culture. Environ Toxicol Pharmacol. 2017;50:103-10.

133. He Y, Zhao W, Dong Z, Ji Y, Li M, Hao Y, et al. A biodegradable antibacterial alginate/carboxymethyl chitosan/Kangfuxin sponges for promoting blood coagulation and full-thickness wound healing. Int J Biol Macromol. 2021;167:182-92. 
134. Chasapis CT, Spiliopoulou CA, Loutsidou AC, Stefanidou ME. Zinc and human health: An update. Arch Toxicol. 2012;86:521-34.

135. Zhang R, Xu N, Liu X, Yan H, Ma J, Feng Q, et al. Dose-dependent enhancement of bioactivity by surface $\mathrm{ZnO}$ nanostructures on acidetched pure titanium. Adv Appl Ceram. 2019;118:121-5.

136. Zhang $\mathrm{R}$, Xu N, Liu X, Yang X, Yan H, Ma J, et al. Micro/nanostructured $\mathrm{TiO} / \mathrm{ZnO}$ coating enhances osteogenic activity of SaOS-2 cells. Artif Cells Nanomed Biotechnol. 2019;47:2838-45.

137. Gao C, Li C, Wang C, Qin Y, Wang Z, Yang F, et al. Advances in the induction of osteogenesis by zinc surface modification based on titanium alloy substrates for medical implants. J Alloys Compd. 2017:726:1072-84.

138. Hie M, Tsukamoto I. Administration of zinc inhibits osteoclastogenesis through the suppression of RANK expression in bone. Eur J Pharmacol. 2011;668:140-6.

139. Yamaguchi M, Weitzmann MN. Zinc stimulates osteoblastogenesis and suppresses osteoclastogenesis by antagonizing NF-kB activation. Mol Cell Biochem. 2011:355:179-86.

140. Choi SW, Choi WJ, Kim EH, Moon SH, Park SJ, Lee JO, et al. Inflammatory Bone Resorption and Antiosteosarcoma Potentials of Zinc lon Sustained Release ZnO Chips: Friend or Foe? ACS Biomater Sci Eng. 2016:2:494-500.

141. Zhou Q, Chen J, Luan Y, Vainikka PA, Thallmair S, Marrink SJ, et al. Unidirectional rotating molecular motors dynamically interact with adsorbed proteins to direct the fate of mesenchymal stem cells. Sci Adv. 2020;6:eaay2756.

142. Oh S, Brammer KS, Li YSJ, Teng D, Engler AJ, Chien S, et al. Stem cell fate dictated solely by altered nanotube dimension. Proc Natl Acad Sci U S A. 2009;106:2130-5.

143. Albrektsson T, Wennerberg A. On osseointegration in relation to implant surfaces. Clin Implant Dent Relat Res. 2019:21:4-7.

144. Hotchkiss KM, Ayad NB, Hyzy SL, Boyan BD, Olivares-Navarrete R. Dental implant surface chemistry and energy alter macrophage activation in vitro. Clin Oral Implants Res. 2017;28:414-23.

145. Yahara Y, Barrientos T, Tang YJ, Puviindran V, Nadesan P, Zhang H, et al. Erythromyeloid progenitors give rise to a population of osteoclasts that contribute to bone homeostasis and repair. Nat Cell Biol. 2020;22:49-59.
146. Li X, Yang Y, Wang Z, Jiang S, Meng Y, Song X, et al. Targeting non-coding RNAs in unstable atherosclerotic plaques: Mechanism, regulation, possibilities, and limitations. Int J Biol Sci. 2021:17:3413-27.

147. Mosser DM, Edwards JP. Exploring the full spectrum of macrophage activation. Nat Rev Immunol. 2009;8:958-69.

148. Zong T, Yang Y, Zhao H, Li L, Liu M, Fu X, et al. tsRNAs: Novel small molecules from cell function and regulatory mechanism to therapeutic targets. Cell Prolif. 2021;54:e12977.

149. Laurenti M, Cauda V. ZnO nanostructures for tissue engineering applications. Nanomaterials. 2017;7:374.

150. Fu X, Zong T, Yang P, Li L, Wang S, Wang Z, et al. Nicotine: Regulatory roles and mechanisms in atherosclerosis progression. Food Chem Toxicol. 2021;151:112154.

151. Raines AL, Berger MB, Schwartz Z, Boyan BD. Osteoblasts grown on microroughened titanium surfaces regulate angiogenic growth factor production through specific integrin receptors. Acta Biomater. 2019;97:578-86.

152. Yang $X$, Yang Y, Guo J, Meng Y, Li M, Yang P, et al. Targeting the epigenome in in-stent restenosis: from mechanisms to therapy. Mol Ther - Nucleic Acids. 2021:23:1136-60.

153. Liu D, Evans I, Britton G, Zachary I. The zinc-finger transcription factor, early growth response 3, mediates VEGF-induced angiogenesis. Oncogene. 2008;27:2989-98.

154. Hou Y, Cai K, Li J, Chen X, Lai M, Hu Y, et al. Effects of titanium nanoparticles on adhesion, migration, proliferation, and differentiation of mesenchymal stem cells. Int J Nanomedicine. 2013;8:3619-30.

155. Aydin EB, Siğircik G, Takci HAM. Antimicrobial properties and corrosion behavior of $\mathrm{TiO}_{2}-\mathrm{NTs}$ electrodes modified with $\mathrm{Ag}$ and $\mathrm{ZnO}$ nanorod in simulated body fluid solution. J Mol Struct. 2021;1240:130569.

156. Shibli SMA, Remya R, Chinchu KS. Nano-ZnO incorporated titania composite coating for orthodontic applications. Mater Res Innov. 2012;16:186-97.

\section{Publisher's Note}

Springer Nature remains neutral with regard to jurisdictional claims in published maps and institutional affiliations.
Ready to submit your research? Choose BMC and benefit from:

- fast, convenient online submission

- thorough peer review by experienced researchers in your field

- rapid publication on acceptance

- support for research data, including large and complex data types

- gold Open Access which fosters wider collaboration and increased citations

- maximum visibility for your research: over $100 \mathrm{M}$ website views per year

At $\mathrm{BMC}$, research is always in progress.

Learn more biomedcentral.com/submissions 